Essays: Part 2: Historical and Philosophical Perspectives 



\section{Unsystematic Vitality: From Early Modern Beeswarms to Contemporary Swarm Intelligence}

“Cette grappe est un être, un individu."1

\section{Materialism, Vital Materialism, and Self-Organization: Enter the Beeswarm}

The eighteenth century was the century of self-organization but also that of materialism, inasmuch as it was then that certain thinkers proclaimed themselves to be materialists (rather than just being labeled as such by enemies of various sorts). ${ }^{2}$ If one seeks to read these two features together - one hesitates to call them 'facts' or 'events' - one arrives rather quickly at an influential metaphor, the beeswarm. But a metaphor of, or for, what? Irreducible organic unity, most broadly - spelled out in the vocabulary of the period in terms of synergy, sympathy, and sensibility, but also of cohesion, consensus, and conspiration: individual bees have their characteristics, their intentions, and their own purposes, but they also 'conspire,' 'cohere,' and 'consent' in the name of a larger living unity, the swarm, although this leaves open further questions such as the exact nature of the order or organization yielded or enacted by the swarm (bottom-up? top-down? emergent? etc.). Bees and their modes of organization have fascinated many observers, and have served as inspiration and/or as metaphors for a variety of ideas, most prominently of the social variety. That is, bees their hive structure for instance, or the existence of a queen - have served as exemplars of social order (although it turns out that only a fraction of bee species are actually social), and of an allegedly innate 'mathematico-architectural' potential in these

\footnotetext{
1 "This cluster is a being, an individual" [Diderot 1975-, vol. 17, p. 120] ("grappe," i.e., "cluster" is a term Diderot uses for the swarm). Unless stated otherwise, all the translations from French and Spanish were done by the authors (S.K/C.W.).

2 On the eighteenth century as the century of self-organization, see: [Sheehan and Wahrman 2015]; on eighteenth-century materialism, see: [Bloch 1997; and Wolfe 2014].
}

\footnotetext{
Acknowledgments: The authors wish to thank Stéphane Schmitt for his suggestions. Charles Wolfe wrote his draft while in residence at the Institute for Advanced Study at CEU (Budapest) and is grateful for the pleasant working conditions.
} 
animals. ${ }^{3}$ By contrast, the phenomenon of the swarm seemed disturbing - less organized, less virtuous - to many such observers. This changed when the beeswarm became a core metaphor for organic, indeed organismic unity and in some cases (notably in Denis Diderot) for the organic or organismic features of living matter itself. It is this story of beeswarms as a mode of organization that we wish to tell.

Materialism has gone through a number of incarnations in its history, a history which itself is a matter of some dispute: are Empedocles, Julien Offray de La Mettrie, and 'new materialists' all part of one history, on one track, one line of development? Materialism has been treated as a particularly nefarious species of 'cold, dead mechanism,' reducing everything in the world - values, feelings, persons, aesthetic experience and so on - to mere 'lumps' of passive matter, ${ }^{4}$ mere aggregates or collections of particles, sometimes even invoking the image of a swarm of bees, as when Jonathan Swift mocks the opinion of "choice virtuosi" that "the brain is only a crowd of little animals" clinging together "in the contexture we behold [...] like bees in perpendicular swarm upon a tree" [Swift 1801, p. 263-264]. ${ }^{5}$ But, as one of us has sought to argue elsewhere [Wolfe 2016, ch. 4; 2017a], we would be wise to put at the center of our histories of materialism the existence of a 'vital,' 'embodied' materialism in which life - organic life, biological life, embodiment, flesh, and blood in contrast to abstract mathematical or otherwise purely physicalistically construed entities - is the core issue. This can be shown on various levels and contexts: for instance, the marked 'anti-mathematicism' of authors like Bernard Mandeville and Denis Diderot (i.e., their view that future programs in medicine, natural history, physiology, etc. should not rely uncritically on the privilege or prestige of the mathematical models derived from the successes of the physico-mechanical sciences of the seventeenth century) ${ }^{6}$ or

3 The interest of early modern and eighteenth-century thinkers in bees, in general, and in the beehive or the beeswarm, in particular, rests upon a long tradition that saw the society of bees as an emblem for human society. From the Renaissance onward, numerous beekeeping manuals based on the observation of nature presented bees as the most profitable insects for man ("What creature for profit can compare to the bee, or the silk-worm?” Purchas asks [Purchas 1657, chap. I, n.p.], while Moffett judges them to be "framed for the nourishment of man" [Moffett 1658, p. 889]) but also "political" insects. On the history of bees as emblems or metaphors, see: [Preston 2005; Woolfson 2010 Prete 1991; Fraser 1931; Quiviger 2003].

4 According to John Hancock, in his 1706 Boyle Lecture attacking the neurophilosophy of Thomas Willis, the brain is a lump of matter "of a clammy and unactive Nature and Substance; [which] seems as far as we can judge of it to be a meer passive Principle, as to the Acts of inward Sensation and Intellection" [Hancock 1739, p. 243].

5 Swift refers specifically, in an unambiguously political gesture, to Hobbes' Leviathan as such a degraded form of unity, like a swarm of bees or "carrion corrupted into vermin" [Swift 1801, p. 264]. 6 For Mandeville, for instance, "the Scheme of bringing Mathematicks into the Art of Medicine is not of many Years standing yet [...] a great length of time must be required before an entire System can be form'd, that shall be applicable to all Cases, and by the Help of which; Men shall be able to explain all Phenomena that may occur" [Mandeville 2017 (1711), p. 110], while for Diderot: "the realm of the mathematicians is an intellectual one: what we take to be rigorous truths absolutely loses this advantage when 
their concern with ideas derived from the 'life sciences' (any combination of medicine, physiology, natural history - 'biology' as such did not exist under that name until the late years of the eighteenth century [McLaughlin 2002; Gambarotto 2017; Wolfe 2019]). It is also at least an amusing fact that the earliest usage of the term 'materialist' seems to have meant 'pharmacist,' in the sense of those who prepared and purveyed the materia medica [Bloch 1978]. Granted this vital emphasis shifts and arguably disappears by the time materialism is reconfigured in post-World War II Anglophone philosophy as 'physicalism' [Wolfe 2016]. But our interest in what follows is to explore an aspect of this vital materialism that is crucially bound up with its appropriation of a core metaphor from eighteenth-century medical vitalism: the beeswarm.

Beeswarms in the early modern period are objects of discussion in varied and colorful contexts, ranging from questions of social and political order to mathematical considerations concerning the hexagonal pattern of beehives. The development of 'mixed' (applied) mathematics from the beginning of the seventeenth century ('pure' mathematics being geometry and arithmetic) had given rise to a wide range of applications, from mechanics to architecture or optics. Demeter and Schliesser take the diffusion of Newton's Principia as a turning point for the "mathematization of all fields of knowledge from natural philosophy through medicine to moral philosophy": the application of principles of geometry to the architecture of the hive is an illustration of this tension between the use of mathematics to understand nature and 'pure' mathematics being necessarily "severed from matter," as Francis Bacon had put it [Demeter and Schliesser 2019]. ${ }^{7}$ These discussions of beehives in fact combine a mathematical focus with a physicotheological reading of hive architecture, as the complex patterns seem to reflect an innate and higher design, something Georges-Louis Leclerc de Buffon was to sneer at later on. In volume 4 of his Histoire naturelle (1753), referring to the great naturalist René-Antoine Ferchault de Réaumur's apiphilia, he stated that a fly (by which he meant any winged insect) should not take up any more room in scientific writing than it does in Nature [Buffon 1753, p. 92 (and more generally, pp. 90-100); Le Menthéour 2009, commentaries; Wallmann 2017]. ${ }^{8}$ Réaumur had asked the mathematician Samuel König to calculate geometrically how the bees arrive at the maximum number of cells with the minimum amount of wax, and by consequence judged that the bees' optimal choice reflects

it is brought down to our earth [...] mathematics, especially of the transcendent sort, lead to nothing particular without experience; they are $a$ kind of general metaphysics which strips bodies of their individual properties" [Diderot 1975-, vol. 9, p. 29, emphasis S.K/C.W.]. For more on anti-mathematicism in the eighteenth century as, not an anti-scientific discourse but a pro-scientific discourse, see: [Wolfe 2017b].

7 For further reading on 'pure' and 'mixed' mathematics, see [Andersen and Bos 2006; Brown 1991; Roux 2010, 2011]; see also [Mancosu 1996].

8 Le Menthéour notes that Bonnet replied to Buffon defending Réaumur's position on the intelligence of bees, in his Considérations sur les corps organisés [Bonnet 1985 (1762), pp. 290-291]. Hoquet suggests that Buffon is less bluntly opposed to Réaumur's position than it appears [Hoquet 2018] - Buffon is 'radicalizing' it instead of opposing it. 
divine wisdom [Réaumur 1740, p. 389]; ${ }^{9}$ his fondness for bees can be seen in his nicknaming them his petit peuple ("little people") [Réaumur 1740, p. 475]. For Buffon, in contrast, the complexity of the cell architecture of beehives was not an indication either of the intelligence of the individual bees or of a higher intelligence of a designer, but rather an emergent property of countless "mechanical interactions," themselves often imperfect, of thousands of "automata” [Buffon 1753, pp. 98-99].

There is no single, monolithic notion of 'machine' in the early modern and Enlightenment periods (nor presumably in any other period): the term could be used to refer to the body (as La Mettrie often did), or often, to theatrical machines producing what we might call special effects. Thus the Dictionnaire de l'Académie defines "machine" in 1694 as "a set of parts or organs which form a whole, living or not, and produce determinate effects without transmitting a force externally; organism, body."10 Equally fundamental here is the fascination with the automaton as a kind of intermediate figure, like a machine but closer to something level. Indeed, the machine often functions as a kind of go-between, enabling the interface between a mechanistic ontology (à la Galileo or Descartes, in which everything reduces to the fundamental properties of size, shape and motion) and heuristics, within which actual machines can serve as 'matière à penser,' so to speak. In Georges Canguilhem's elegant phrase: “Essentially, a machine is a mediation or as mechanics say, a relay (relais)" [Canguilhem 1965, p. 87]. Interestingly, by the nineteenth century the situation is different, with the Encyclopédie méthodique explaining (in 1808) that one should no longer use the expression 'machine humaine' but, instead, for example, 'organism,' because "the term 'machine' seems to refer to a system of causes and effects which belongs wholly to the mechanistic theory."11

But in all these contexts, the real object of interest is organization: whether in the 'built' form, like their hives, or in the curiously 'emergent' form, like their swarms, ${ }^{12}$ the way in which bees seemed to generate a mode, or different modes, of organization what later theorists of self-organization would call 'order for free.' We first discuss early modern interpretations of the phenomenon of swarming in bees, which are inseparably 'sociopolitical' and 'metaphysical,' inasmuch as they call attention both to the nature of social interaction, order and disorder, and political régimes (if bee societies should serve as inspiration for human societies, it is indeed crucial to decide whether the former are monarchical or republican) and to the nature of unity and disunity themselves, as core

9 The result of the calculation was close to that which had been found by Maraldi [Maraldi 1712]. See also Fontenelle's presentation of Maraldi's work in the Mémoires de l'Académie Royale des Sciences, 1712, pp. 5-12.

10 Dictionnaire de l'Académie, cited in [Cayrou 1948, p. 530].

11 "Machine," in [Encyclopédie méthodique 1808, p. 310].

12 The distinction between the swarm and the hive is not that clear-cut. Both behave in the same way, although technically the swarm announces the colonization of new hives. 
principles (for biology but also for questions of identity more broadly). Thus the editors of a recent, influential collection of essays on current evolutionary-biological perspectives on individuality amusingly observe that while Charles Darwin had written in his notebooks, "He who understands baboon would do more towards metaphysics than Locke," today, it is more an issue of 's/he who understands beehive': "When one replaces 'baboon' by 'beehive,' one starts to appreciate the complexities of biological individuality and why we must explain how, from the many, one can emerge" [Bouchard and Huneman 2013, p. 11]. We then turn to the beeswarm's association with materialism in the early modern context, as a kind of chaotic (Lucretian) multiplicity of forces, and then to the specifically eighteenth-century vitalistic development of this metaphor, in which it occupies center stage (now in an entirely positive, non-pejorative sense), and its philosophical (indeed, materialist-philosophical) reappropriation by Diderot, before concluding with some reflections on swarm intelligence, emergence, and attempts to devise swarm algorithms, in a marked focus on the swarm as a kind of mind versus as a kind of life (as in, e.g., earlier vitalist discussions).

\section{Beeswarms: Order or Disorder?}

The beeswarm offers the powerful image of a collection of "little bodies," as Samuel Purchas calls them, that have no existence outside the single organism they constitute. Comparing the single bee to "a drop of water" that "hath no power" compared to the seas, or to a "spark of fire" that lacks the destructive power of "the communion of many flames," Purchas describes the swarm as the only beneficial form of organization for the bee: "una Apis, nulla Apis, one Bee is no Bee, but a multitude, a swarm of Bees uniting their forces together, is very profitable, very comfortable, very terrible, profitable to their owners, comfortable to themselves, terrible to their enemies" [Purchas 1657, p. 16]. The single bee as a self-sufficient, autonomous part is not to be found in early-modern conceptions of nature. For Margaret Cavendish, the necessary gregariousness of the beeswarm illustrates the continuum of matter in nature, where inanimate and animate matter form "a single, continuous, self-subsistent organism" in which “self-subsistent atoms” [O’Neill 2013, p. 316] cannot exist:

Nature would be like a beggar's coat full of lice: Neither would she be able to rule those wandering and straggling atoms, because they are no parts of her body, but each is a single body by itself having no dependence upon each other. Wherefore, if there should be a composition of atoms, it would be a body made of parts, but of so many whole and entire single bodies, meeting together as a swarm of bees.

[Cavendish 2001, p. 129]

The various theories on the generation of bees that were popular until the second half of the eighteenth century reinforced the idea of a continuity between inanimate and animate matter, as bees were believed, like most crawling or flying insects, to swarm from the carcasses of dead animals or from "putrefaction" [Moffett 
1658, p. 897]. ${ }^{13}$ The collective body of bees, variously described as "a large parcel," a "stock of bees" (John Thorley), or a "lump of Bees" (Joseph Warder) appears as shapeless as the cells of the beehive are regular and ordered. Cavendish, however, sees the swarm as a perfectly defined shape as the bees gather "in a round Figure or Globe, like the world; which shews the round figure is not only the most profitable, having the least waste, and largest compass, but the securest Figure, being the most united, not only by drawing in all loose and wandering parts, but combines them all together with a round Circle Line" [Cavendish 1656, p. 163]. ${ }^{14}$ Although the image of the harmonious orb is unusual, the physical unity of the swarm mirrors the unity of the community of insects, the close-knit throng functioning as a single-bodied organism. Influenced, no doubt, by Purchas and other authors of beekeeping treatises, Robert Boyle uses the example of the beeswarm to discuss the motion and cohesion of bodies that are firmer than fluids though not entirely solid:

I have more than once taken pleasure to look upon an heap of swarming Bees, for though they
make not up a liquid but coherent body, which may be turn'd upside down without losing its
coherence, and which being beheld at a distance, seems to be one entire mass or body; yet it is
evident to him that looks at them near enough, that the particular Bees that swarm have most
of them their distinct and peculiar motions, and that yet these motions of the particular Bees
destroy not the coherency of the heap; because that when one of the more innermost Bees re-
moves, as she lets go her hold from those that she rested on before, and goes away from those
that rested on her, so she meets with others on which she may set her feet, and comes under
others that in like manner set their feet on her, and so by this vicissitude of mutual supports
their coherence and their removes are made compatible; and if instead of Bees, the swarm con-
sisted of extreamly little flies, their particular motions would perhaps be inconspicuous. ${ }^{15}$

[Boyle 1772, p. 399]

However incoherent the movement of each individual corpuscle or bee may seem, the swarm is perceived as a coherent whole, moving in one single direction.

Cavendish also describes the swarm or "commonwealth" as "one body, or rather, all those little bodyes are as one great Head, or rather, as one Minde, and their influence united by a general agreement, as one Minde” [Cavendish 1656, p. 162-163]. John Thorley resorts to an equivalent comparison between the swarm of bees and the united body and mind to describe the uniform volition and concerted actions of the bees: "If Soul and Body are once separated, the Man dies [...] These little Creatures thus firmly knit together in sincere affection, and combination in Power, appear effectually secured from all Assaults and Enemies” [Thorley 1744, p. 14]. As early as the

13 [Worlidge 1676, pp. 4-5] confirms that bees "are sometimes engendered by putrefaction" and quotes Virgil's Georgics: “A wonder not to be believed, he sees/From the dissolved Entrails, Swarms of Bees.” See: [Tunstall 2016, pp. 207-211; Baine Campbell 2006].

14 Baine Campbell links the circular shape of the bee colony to the round shape of the utopian space, see: [Baine Campbell 2006, p. 621].

15 On bees and particularly swarms in Boyle, Purchas, and Hartlib, see: [Schmidgen 2013, pp. 99-100]. 
seventeenth century, the fascination for the swarm was expressed not only as an interest for life and matter but also for swarm cognition and intelligence, a topic to which we will return in closing. The cohesion of the swarm is the condition of the bees' survival, for, as Cavendish points out, "they know that if the commonwealth be ruinated, no particular person can be free” [Cavendish 1656, p. 163]. Thorley also describes swarms as bodies of interdependent bees moved by the common good:

They are a Body Politick, and cannot live separate and alone. A Bee, as a solitary Insect, and without her Company, is an insignificant, impotent, helpless, useless Creature; cannot work, nor propagate her species, nor secure herself from numerous Enemies and Evils. But what noble, excellent Purposes do they serve, thus incorporated; and by a social Spirit thus strictly united together jointly pursuing the Publick Profit and Advantage. [Thorley 1744, pp. 12-13]

The collective success of the commonwealth depends, for Thorley as for the majority of these authors, upon its cohesion and consistency.

\section{Are Bees Royalists or Republicans?}

The beehive itself was an ancient metaphor for political order (at least as far back as Plato, and Aristotle $\left.{ }^{16}\right]$. Indeed, whether used in a scandalous fashion like in Mandeville, or in a virtuous fashion like in many other authors, honeybees (Apis mellifera) were most often taken as exemplars of good, useful, productive social interaction of industry - as was the beaver, and also of altruism: "The bee nation was perceived to cooperate as a group of comrade-members, a commonwealth in which the individual subsumes herself in the collective enterprise and good of the colony, and each bee acts for the general benefit of all the other bees" [Preston 2005, p. 53].

As naturally social insects, bees were systematically held up as an example for the human polity in the early modern context: "A Bee, like a man cannot live alone, if shee be alone, shee dies," writes Purchas who further describes bees as "political creatures" that "destinate all their actions to one common end," their commonwealth being comparable to the body "in the Fable of Menenius Agrippa" which died "when the rest of the members to ease themselves wronged the belly" [Purchas 1657, pp. 16-17]. Some authors also resort to a martial metaphor ${ }^{17}$ to describe this apian society as a top-down

16 On Aristotle, see: [Aristotle 1965, 488a33 ff.]; cf. [Johach 2007] - although Aristotle also states that human beings are more political animals, than bees [Aristotle 1984, 1253a8].

17 On the origin of the bees as war-mongering soldiers, see: [Freeman 1980, pp. 186-188]. The martial metaphor or simile is also frequently used in medical treatises to describe the similar functioning of another form of swarming, that of the animal spirits. See, for example, Thomas Willis, who insists on the unity of the animal spirits in action as they "allways agree mutually between themselves, and intimately conspire together" and adds: "the Spirits contiguous one with another are set like an Army in Array” [Willis 1683, pp. 23-24]; see also: [Willis 1679, pp. 137-138]. 
organization placed under the authority of a unique leader. Those who were convinced that the swarm was under female rule, described the bees as fierce Amazons or compared them to the "Female troops of Thrace" [Dinsdale 1740, pp. 16-17]. Bees have to form "a disciplined army" [Arbuthnot 1728, p. 7], ${ }^{18}$ driven by "mutual emulation" to maintain the indivisibility of the swarm, which is perpetually threatened by its own collapse or disunion. For some authors, their "thronging legions" [Dinsdale 1740, p. 23], described as "a numerous army, strongly entrenched, in which every common Soldier was a perfect Hero, that would sooner die than yield," taught by nature "to hate and abhor Riots, Tumults, Treasons, and Rebellions" [Thorley 1744, p. 10], do not form a self-governing commonwealth striving as a "single Minde" for the common good, but a regiment of "submissive bees" acting under the authority of one "Royal Mind" [Dinsdale 1740, pp. 16-17].

If for Cavendish "the general agreement" holds the swarm together, it does not imply that the organization of the commonwealth should be strictly horizontal and egalitarian. In his poem on beekeeping, Joshua Dinsdale reverses the Mandevillian trope from The Fable of the Bees and suggests that bees used to form an ideal republic and were imitated by men until men, unlike the frugal bees, became deluded by luxury and lost sight of the common good: "Thus Hives were first with Golden Honey fraught, / And their Republics sharpen'd human Thought, / Inspir'd, with Love of Public Good, Mankind, / 'Till Fraud and Luxury debauch'd the Mind” [ibid., p. 4]. By tradition, however, the political model associated with the commonwealth of bees is that of a monarchy, the anthill being, in nature, the incarnation of the republic. For Cavendish "the Ant and the Bee resemble more in their wise industry than in their government of the Commonwealth, for the Bees are a Monarchical government, as any may observe, and the Ants are a Republick" [Cavendish 1656, pp. 164-165]. ${ }^{19}$ But she further refuses to assign greater value to one or the other, and concludes: "The monarchical Commonwealth of the Bees is as wise and as happy as the Republic Commonwealth of the Ants" [ibid., p. 165]. For others such as Thorley, who underlines the difference between the commonwealth and the monarchy, only the ants live in "a Democracy, or Common-wealth, having no overseer or ruler" [Thorley 1744, p. 47]; bees, he insists, have instinctively formed into "a most compleat and admirable Monarchy, the original and most natural Form of Government" [ibid., p. 43]. In his Feminine Monarchie, Charles Butler stresses their natural abhorrence for both polyarchy and anarchy, and their creation by God to set for men the example of the "perfect monarchie, the most natural and absolute form of government" [Butler 1609, ch. 1, (A3)]. While it is tempting to contrast an eighteenth-century, Rousseauean

18 For the anonymous author of The Congress of Bees - Arbuthnot - the bees are more "valiant Warriors" and "puissant Heroes" [Arbuthnot 1728, p. 7] than Swift's Lilliputians or Dryden's Pygmies; see also: [Moffett 1658, p. 891].

19 On commonwealths of insects, and more particularly on ants and bees, see: [Hobbes 2012, pt. II, ch. 17]. 
reading of bee societies as radically republican and egalitarian, with earlier monarchist visions of the same, ${ }^{20}$ in fact tensions between the two readings always existed. After all, Miguel Cervantes in Don Quixote had already described the beeswarm as a republic presented as the emblem of Arcadian abundance. ${ }^{21}$

The monarch ensures the unity and cohesion of the commonwealth of bees, but whether the ruler was a king or a queen was still a matter of debate in the eighteenth century, mainly because of conflicting theories regarding the generation of bees. As late as 1795, a curious episode concerning bees took place at the Revolution-era École normale in Paris (to be precise, in year III of the Revolutionary calendar, which spanned 1794-1795). The naturalist Louis Jean-Marie Daubenton was ridiculing Buffon's 'anthropomorphic' presentation of the lion as the 'king of the jungle,' when a particularly misogynistic student named Laperruque (literally, The Wig) jumped up and declared, "much worse than the king is the queen!," referring to the queen bee: "more extraordinary still, a queen within a republic" [Daubenton 1800, p. 92]. ${ }^{22}$ Lions, he continued, are simply feared by their subjects whereas bees are genuine courtiers, surrounding the queen and protecting her. Daubenton responded that the queen, who he preferred to term the "female bee," is just an egg-layer; the real power lies with the worker bees, who only respect the others (female and male) because they are needed for the reproduction of the species [Daubenton 1800, p. 93]. Daubenton nevertheless emphasized the role of the queen, including in the case of swarms: "the swarm would not subsist if it did not have any queen, that is to say, a female bee [...]. Whenever there is no female bee in a swarm, it soon goes back to its former hive" ("l'essaim ne subsisteroit pas s'il ne s'y trouvoit une reine, c'est-à-dire une abeille femelle [...] lorsqu'il n’y a point

20 Thus, Gaukroger notes that bees had traditionally been considered a model monarchical community (referring to influential texts such as [Butler 1609], [Purchas 1657], [Warder 1712], and [Thorley 1744], which we discuss here - but, as we note above, this was not always the case (it is in fact possible to see a tension between monarchical and republican 'readings' of beehives and swarms as always present, in beekeeping texts and in more explicitly political and/or theoretical texts) [Gaukroger 2010, p. 401, footnote 35].

21 "En las quiebras de las peñas y en lo hueco de los árboles formaban su república las solícitas y discretas abejas, ofreciendo a cualquier mano, sin interés alguno, la fértil cosecha de su dulcísimo trabajo"; in Smollett's eighteenth-century English translation, the bee republic became a commonwealth: "In clefts of rocks and hollow trees, the prudent and industrious bees formed their commonwealth, offering without interest, to every hand the fruitful harvest of this delicious toil" [Cervantes de Saavedra 1755, I, p. 54]. On bees in Don Quixote, see: [Brewer 2014, pp. 34-36; Cascardi 2012, esp. pp. 63 and 156].

22 Thanks to Stéphane Schmitt for this reference; cf. [Drouin 1992, p. 333]. D. Allen mentions a medieval charm against swarming that refers to the bees as feminine ("victor dames") [Allen 2003, p. 96n.]. Some authors of the period describe the queen as a 'mother bee' (on gender politics within the hive see: [Prete 1991]), while it is startling to see Maraldi, in his impressive report on bees to the Académie des Sciences in 1712, referring to the queen as "le Roy" [Maraldi 1712, p. 9]. As for the link between bees and lions, it is actually biblical (Judges 14:8), as discussed already by Moffett in the seventeenth century (see above). 
d'abeille femelle dans un essaim, il revient bientôt à l'ancienne ruche” [Daubenton 1966 (1757), 994b]).

Jeffrey Merrick has called attention to the role of the microscope in the evolution of the theory regarding the gender of the apian monarch, as it unraveled the mode of reproduction inside the hive, and with it its "moral and political perversity" [Blum 1988, p. 5; Merrick 1988]. Some authors such as Butler (Feminine Monarchie), Warder (The True amazons: or, the monarchy of bees), or Thorley (The Female Monarchy) displayed their opinions on the subject in a programmatic title, the natural benevolence of the queen bee confirming the "just and kind" exercise of absolute sovereignty while ensuring the remarkable fertility of the commonwealth. ${ }^{23}$ For others such as Moses Rusden, bees are governed by a male king who fertilizes the "animable matter" disposed in the cells, while the honeybees "are the Female, but not by virtue of any Copulation or Conception, but because they supply the place and Office of the Female" [Rusden 1685, p. 42]. King or queen, the monarch of the beehive is not presented as a brutal autocratic ruler (however prone to wage war on other insects) but as a benign sovereign, equipped either with an innocuous, poisonless sting, which is to be understood as a symbol of its authority, or with a lethal sting it only uses against enemies or rival princes. The physical characteristics of the monarch are natural elements of distinction that set it apart. Thomas Moffett reports in his seventeenth-century Theatre of Insects that according to some "curious searchers into the work of nature," the 'matter' bees are made of conditions their social role and behavior:

The best and noblest bees are generated and bred out of the Lion, and the Kings and Princes of them do derive their pedigree and descent from the brain of the Lion, being the most excellent part of his body: it is no wonder therefore if they, proceeding and coming from so generous a flock, do assail the greatest beasts, and being endures with Lion-like courage, do fear nothing.

[Moffett 1658, p. 891]

The "king of the whole swarm," which, for Moffett, is elected by the other bees for its natural superiority, is "always of an excellent shape and twice as big as any of the rest." It is all the more exceptional, since it is "not begotten a little worm at the first, as the Bees are, but presently able to fly” [Moffett 1658, pp. 891, 892]. While Rusden's monarchical hive is ruled by "a natural King, and set apart by Nature herself” [Rusden 1685, p. 17] and monarchy is passed on to the royal heirs, for Moffett the monarch's election guarantees the unity of the civitas: "Bees are swayed by Soverainty, not by Tyranny, neither do they admit of a King properly so called by Succession or by lot,

23 For Mary Baine Campbell, treatises on beekeeping were willing "to distort their closely observed accounts of bee sociability in the service of maintaining the power of the bee 'polity' to analogize, and thereby to authorize, prevailing norms such as gender hierarchy in government, the superior usefulness of male labor, or the chastity and monogamy of women" [Campbell 2006, p. 622]. On the gender of the apian monarch, see Prete [1991]; and on the hive as a model for human polity, see: [Campana 2013; Merrick 1988]. 
but by due advice, and circumspect choice; and though they willingly submit to regall Authority, yet so, as they retain their Liberty; because they still keep their prerogative of election" [Moffett 1658, p. 892]. Purchas offers a discordant vision of the nature of monarchy in the apiary. All the actions of those "political creatures" have "one common end" and they all "aim at the publick welfare" [Purchas 1657, p. 34], but they strive "under one Commander, (who is not an elected Governour" [ibid.]. For Purchas, who also imagines "an Amazonian Commonwealth" governed by a "Queen Bee”), notwithstanding the fact that the swarm is unanimously preoccupied by the common good in all its actions, the bees cannot be entrusted with the choice of their ruler "for the vulgar often want judgement, raising the worst and wickedest to the Throne" [Purchas 1657, p. 16].

However indispensable to the general happiness and productivity of the hive, and more importantly to the political cohesion of the commonwealth, the king or queen can also be the cause of its division. The ruler's untimely death would lead to "the certain and total Destruction of the State" [Thorley 1744, p. 7], overturning the natural order of the commonwealth and threatening the regeneration of the swarm: "But the King being dead, the subjects are perplext, the Drones lay their young ones in the Bees cells, and all things are out of order" [Moffett 1658, p. 892]. Having no king or queen would lead the community of bees to its collapse, but more than one monarch would be equally dangerous. Faced with conflicting sources of authority, the bees would no longer be able to perform their respective duties: "under two or more Kings they will not be, for they will neither work, nor breed, nor be quiet” [Rusden 1685, p. 16]. For Moffett, however, the bees will protect the "Master Bee" at the peril of their lives as the indispensable protector of the indivisibility of the swarm, but only insofar as he is not tempted to yield to his own selfish and tyrannical passions: "much less do they put him to death, unless as tyrants are wont he makes his lust the rule of his Government, or being negligent of the Common-wealth, takes no care of it” [Moffett 1658, p. 893].

\section{Swarming}

In some cases, the metaphor of the swarm is strongly opposed to that of the hive. Yet as we discuss below with respect to the specifically 'biological' uses of the beeswarm metaphor, both images illustrate the same general idea of organismic unity. ${ }^{24}$ Granted, bees swarm when it is time to leave a hive and found a new one, and in that sense, the swarm is a transient state, but that does not mean that it has nothing to do with organismic unity, on the contrary. In the early modern discussions, swarming - the planned or accidental division of the civitas into several colonies - is seen as happening either when a younger prince tries to rise to power or when the hive becomes too populous

24 On metaphors of organism overall, see: [Schlanger 1971]. 
and the threat of sedition arises. Joseph Campana points to the fact that the division of the close-knit commonwealth is prompted neither by gender issues nor by class conflict; the new swarm is formed under the pressure of the younger bees eager to cluster around a new ruler [Campana 2014, p. 72]..$^{25}$ Dinsdale describes swarming as the bold move of conquerors extending the boundaries of an empire:

When now the Hive too populous appears, / And the wise Regent a sedition fears, / She strait exhorts the Youth their Lot to try, / [...] And the Foundation of an Empire lay. / [...] Strait little Clangors give the shrill Alarm, / And animate the young advent'rous Swarm; / They flock their new-elected Queen around, / And pant for Glory at the martial Sound.

[Dinsdale 1740, pp. 22-23]

The division of the apian organism through swarming is comparable to cell division as it produces a new organism (a new swarm clustered around a new monarch) and also extends the more shapeless body of bees over an ever-growing territory, extending the apian dominions over some other "Rock or clefted Tree" [Dinsdale 1740, p. 22]. Swarming is a driving force, but it also threatens the commonwealth with partial or complete destruction if the new monarch is lost on the way or if the old monarch is opposed to the departure of some of its subjects (an opposition which for Moffett justifies regicide).

Even when it is ruled by a benevolent monarch, and however inspired by the common good, the industrious swarm as a 'body politick' is paradoxically further threatened by its own parts. The general idea of a harmonious community of selfless bees put forward by all the early-modern authors of bee-keeping manuals hides a more divided social model, which harbors selfish passions and other vices. The swarm is in fact not exactly as uniform as it would seem, and besides the hardworking, disinterested honeybees and their respected king or queen, another kind of bee, the male bee or drone, is an element of potential disruption. Conspicuously absent from Dinsdale's ideal swarm, the drone was, as Campana observes, "a central node of anxiety" for many of the authors we discuss [Campana 2014, p. 71]. For Cavendish, they are human-like bees that do not aim at the common good but take advantage of the work of others: "Men are not like Beasts, to Work for a General Profit, but like Drones, to Rob the Particular Labours of the Commonwealth." ${ }^{26}$ Drones seem

25 Campana quotes Thomas Hill, who explains swarming as a necessity for the younger bees: "for such is the nature and propertie of the bees, that assoone as the swarme of the yong bees are bred with the kings, and they be strong \& able to flie away, then as disdaining the swarms of the old bees, they seeke the more government. For they be such living things as delight to rule alone, not seeking aide or counsel of the elder bees" [Hill 1608, p. 14].

26 And Cavendish adds: "neither is it amongst Mankind as amongst Beasts, for amongst Beasts there are more Bees than Drones, but amongst Mankind there are more Drones, as I may say, than Bees, that is, there are more Unprofitable, than Good Commonwealths men" [Cavendish 2012, letter 205, pp. 220-221]. For Cervantes also, if the republic of bees in general is a model for the human polity, the drones are the paradoxical apian incarnation of human passions within the hive: "For I would have you know, my friends, that your idle and lazy fellows are the same in a commonwealth as drones in a bee- 
to form a community of their own, although they are indispensable to reproduction either because their role is, according to some authors, to impregnate the queen or because they heat the hive by their presence alone, allowing the young bees to grow. Rusden presents them as the defenseless victims of the ruthless honeybees but insists on the fact that "no colony or stock can well strive without them" [Rusden 1685, p. 8]. ${ }^{27}$ While Purchas seems to consider them idle but useful, for the vast majority of authors their usefulness is questionable. For Samuel Hartlib, their presence is endured until swarming takes place, but their supposed role is not even worth mentioning: "There is in every Hive a great number of attendants somewhat larger than the Bees (we call them Drones) which are fed by the labours of the Bees as long as they prepare for Swarming; but as soon as the Bees resolve to send out more Colonies, they fall upon the Drones and kill them" [Hartlib 1655, p. 13]. ${ }^{28}$ Moffett differentiates between older and less productive honeybees - even those who "can do nothing at all" - and drones: "for they do not as they do, spoyl the Combs and steal the Honey" [Moffett 1658, p. 893]. In the first decade of the seventeenth century, John Day imagined a short play in which the bees express their grievances in the Parliament presided over by Prorex, the Master-Bee. They complain of several insects personifying weaknesses or moral flaws, such as Parcimonious, the "thrifty bee" or Pharmacopolis, the "quacksalver." Various petitions against mortal enemies of the hive are also presented to the magistrate. Among these enemies is "the surly Humble Bee" who "will neither pay / Honey nor Waxe, doe Service, nor obey," and "by Stealth / Makes dangerous inroads on your common-wealth, / Robs the day-labourer of his Golden Prize," but also "the lazie Drone":

Our native Country Bee, who like the Snaile

(That bankrowt-like makes his own Shell his Jayle

All the day long) Ith' evening Plaies the thief,

And when the laboring Bees have tane reliefe,

Begone to rest, against all right and lawe

Acts Burglary, breaks open their house of straw,

hive, that consume the honey which the industrious labourers have made" ("Porque quiero que sepáis, amigos, que la gente baldía y perezosa es en la república lo mesmo que los zánganos en las comenas, que se comen la miel que las trabajadoras abejas hacen" [Cervantes de Saavedra 1755, II, p. 301]).

27 About the drones, he writes: "they have neither stings nor fangs, which is the reason why they are so easily beaten and killed by the Honey Bees, having no Weapons offensive or defensive” [Rusden 1685, p. 7].

28 (This is a collection of letters and notes on bees, only some of which are by Hartlib himself.) Moffett also emphasizes the violence that characterizes life in the orderly hive, in which deformity and imperfection cannot be tolerated even among the workers themselves: "And if the chance to find among young ones any one that is a fool, unhandsome, hairy, of an angry disposition, illshapen, or naturally ill-conditioned, by the unanimous consent of the rest, he gives order to put him to death, lest his souldiery be disordered, and his subjects being drawn into faction, should be destroyed" [Moffett 1658, p. 892]. The unity and cohesion of the swarm is also conceived as resting upon the uniformity and homogeneity of its parts. 
And not alone makes pillage of their hives,

But (Butcher-like) bereaves them of their lives. ${ }^{29}$

[Day 1641, n.p.]

As opposed to the humble bee or to other alien foes such as the "cruell waspe," the drone is the enemy from within, like a cancerous cell set on destroying the organism that harbors it. As any living organism would oppose a tumor, the worker bees turn against the drones and kill them to prevent the self-destruction of their commonwealth. The process is thus described by Moffett:

The Dors also and Drones they kill as often as they want room for their works (for they take up the innermost part of the Hive) and take away from them both their honey and their victuals. As also when their honey fails and there is a dearth then they go pell mell among themselves, and fight as it were for life and bloud, the short bees they fall upon the long, the smaller sort set upon the Drones (as idle and unprofitable).

[Moffett 1658, p. 894]

The conclusion of these intestine wars is unpredictable, but for Moffett the annihilation of the drones and the corollary survival of the shorter bees will yield "an excellent swarm" [Moffett 1658, p. 895].

Some of these tensions between republican and monarchical readings of the bee collective also reflect different attitudes toward the question of instinct, which we have not discussed here. For most of the texts surveyed above tend to present the hive as acting instinctively for the common good, but on the other hand it also requires a benevolent and just monarch, otherwise the entire collectivity qua system collapses (implying that queen bees can be 'bad' and that without a chief whip, bees can follow something else than the common good, despite their instinct for what ensures the common good).

In the vast majority of texts on beekeeping and texts that use the commonwealth of bees as a model for human polity, the swarm or hive as a steady and uniform body preoccupied by the common good always contains the ferments of its own ruination or obliteration. To have more than one monarch is a threat, but ambitious princes trigger swarming and therefore the regeneration and extension of the species. Drones are useless thieves, but by their very presence they allow the newly hatched eggs to grow into honeybees. In the Fable of the Bees, Bernard Mandeville's "grumbling hive" takes after this long and consistent tradition [Mandeville 1924 (1714, 1729)]. Mandeville uses this rich literature on bees and plays with its internal contradictions. His hive full of knaves works toward to the common good, despite the cracks in its close-knit unity. For all its violence, for all its cheating and honey-gorging individuals, the Mandevillian hive is like the hives described by Moffett and others: a coherent community within which private vices do mean public benefits.

29 Fairfax Withington, points to the fact that pre-republican America identified the unproductive drone with British custom officials who came in swarms to "destroy crops" and feed on "the productivity of the colonies" [Withington 1988, p. 44]. 


\section{Disturbing Swarms: Beeswarms and Materialism}

We have already seen how beeswarms served as exemplars of different kinds of order and organization and, in authors such as Cavendish, how they could also function as heuristics (i.e., heuristically charged metaphors) for more abstract considerations of unity and disunity, mereology and overall the identity of what one might call 'dynamic wholes,' powered by the constant interaction of their living parts, and the emergent properties thereof. They are never just something merely natural, or "simply there," as Donna Haraway remarks about a very related notion, that of organism: "Politically and historically, I could never take the organism as something simply there. I was extremely interested in the way the organism is an object of knowledge as a system of the production and partition of energy, or as a system of division of labour with executive functions" [Haraway 2006, p. 136]. But swarms could also be seen as disturbing, as is still conveyed in the German expressions Schwärmen and Schwärmerei. We have already mentioned Swift's sharp dismissal of materialist claims concerning the inherence of mind, soul or self in such an organ as the brain, using the image of the beeswarm to hammer in the impossibility of such inherence: the unity of thought, consciousness, selfhood, self-awareness, and so on are irreconcilable with the idea of the brain as a mere "swarm of Bees" [Swift 1801, pp. 263-264].

Samuel Clarke had already argued in familiar post-Cartesian terms that the soul cannot be material because consciousness is indivisible, while matter is divisible, but Clarke also pointed to what we might call the problem of biological-personal identity. He suggests that we imagine "three or three hundred Particles of Matter, at a Mile or any given distance one from another; is it possible that all those separate parts should in that State be one individual Conscious Being?" Suppose then that "all these particles" are brought together "into one System, so as to touch one another": will they thereby, "or by any Motion or Composition whatsoever," become "any whit less truly distinct Beings, than they were when at the greatest distance? How then can their being disposed in any possible System, make them one individual conscious Being?" [Clarke 1731, pp. 23-24]. In later eighteenth-century reactions against materialism, this is repeatedly heard in different variations. For the Abbé Nicolas-Sylvestre Bergier, if the brain is a mere "heap of molecules of matter," how could "a simple and indivisible act such as willing be attributed to the brain?" Bergier rejects the key organismic premise of the beeswarm metaphor without mentioning it specifically, stating that a collection of wills or minds can never amount to one will or mind [Bergier 1771, p. 176]. In his very visible and influential Boyle Lecture (the first of the series) against atheism, Richard Bentley had specifically rejected materialist ideas of vital, embodied matter with reference to the beeswarm:

a great number of... living and thinking Particles could not possibly by their mutual contract and pressing and striking compose one greater individual Animal, with one Mind and Understanding, and a Vital Consension of the whole Body: anymore than a swarm of Bees, or a crowd 
of Men and Women can be conceived to make up one particular Living Creature compounded and constituted of the aggregate of them all.

[Bentley 1693, p. 13 (emphasis S.K/C.W.)]

Unlike Samuel Clarke and Bergier, Bentley is not just worried about chaos and the loss of the unity of the person; he is also concerned, somehow, with what will become a positive, ideologically neutral claim in the medical vitalists we discuss in the next section, and then again a 're-materialized' claim in Diderot (as we discuss subsequently): that each parcel of organic matter (or matter in general) could come to be a 'life' of its own: "Every Stock and Stone would be a percipient and rational Creature. We should have as much feeling upon the clipping off a Hair, as the cutting off a Nerve" [Bentley 1693, p. 13]. Seen from the standpoint of the early twentieth century and beyond, this vision of the beeswarm is ironic, given that it became instead the image - a living argument, as it were - for organicism rather than materialism! (We briefly discuss the work on 'social insect collectives' and the idea of 'superorganisms' associated originally with the entomologist William Morton Wheeler in closing.) But the first step in that direction was to reconfigure the beeswarm as a core metaphor for organic unity, in other words, for the identity of organisms as distinct from mere mechanisms, heaps of matter, or other assemblages lacking the newly discovered and discussed features of organic interconnection and thus self-organization.

\section{The Beeswarm as Scientific Metaphor: Vitalism}

We now come to the crucial passages concerning the beeswarm in a vitalist context, or rather, more broadly, in a context in which it serves the purpose of metaphorically expressing the structural and relational feature(s) of organismic unity. The context shifts in that the swarm is no longer discussed in terms of sociopolitical order (or disorder), nor as a source of anguish regarding materialism and disorder, but rather as a legitimate heuristic for biological and medical thought broadly construed. It is first used in this sense (as grappe d'abeilles or groupe d'abeilles) by the famous naturalist Pierre Louis Moreau de Maupertuis, Secretary of the Berlin Academy of Sciences, in his Système de la nature (1751), then in a series of writings from the medical thinkers we now know as the 'Montpellier vitalists"30 (notably by Théophile de Bordeu

30 The term 'Montpellier vitalists' is generally used to refer to the group of physicians and professors of medicine (but also anatomy, botany, etc.) at the Faculty of Medicine in Montpellier, beginning in the mid-eighteenth century; the term "vitalist" was applied to this group since at least the 1790s, and indeed served as a self-description during those decades [Rey 2000; Williams 2003; Wolfe and Terada 2008]. Significant figures of this school include Louis de La Caze (1703-1765), Théophile de Bordeu (1722-1776, also known for his appearance as a fictional character in Diderot's Rêve de D’Alembert), Henri Fouquet (1727-1806), Jean-Joseph Ménuret de Chambaud (1739-1815), 
and Jean-Joseph Ménuret de Chambaud), and finally in Diderot, from the mid-century to the late 1760s. The basic intuition centered around a way of describing the organism (or 'animal economy,' in the period's vocabulary) that did not treat it strictly in mechanical or mechanistic terms, but rather, as a whole formed of parts which have, or are, independent lives. With Diderot, the beeswarm is transposed from 'vitalist medicine' to 'materialist philosophy,' in his then-unpublished Le Rêve de D'Alembert (1769) [Duflo 2003; Wenger 2012, p. 40].

In his Système de la nature, which bears the more informative subtitle Essai sur les corps organisés, ${ }^{31}$ Maupertuis gives the shortest and also simplest statement of the beeswarm metaphor. His concern is how to illustrate the dynamics whereby organisms are formed out of various organs or parts, and this is where the metaphor comes in. How is it that a body is composed of thousands of elements that somehow 'knew' how to place themselves in the right position in the course of embryonic development? Like in the case of "an army seen from a distance," which "might appear to us as a great animal" (an ancient image, and one which Boyle had also applied to the beeswarm, as we saw above), similarly, "a bee-swarm, when the bees are assembled and united on the branch of a tree, only presents to our gaze a body lacking any resemblance to the individuals which composed it." The outward appearance of a beeswarm leads us to disregard that it is composed of thousands of tiny insects [Maupertuis 1756, pp. 154-155].

Bordeu makes much more extensive use of the image, in his most celebrated work, the Recherches anatomiques sur la position des glandes et leur action (also from 1751), in a section revealingly entitled "How to understand the action of all the parts, their departments, and their periodic motions” (§ CXXV). After a long analysis of the relations between the "general" circulation and "particular" (or "specific") circulation, which Bordeu describes in Hippocratic terms as being like "small circles which gradually form a larger one," ${ }^{\text {,2 }}$ as well as between different types of blood vessels, raising issues of 'communication' between parts, ${ }^{33}$ Bordeu acknowledges that he has to resort to a metaphor (he initially says a "comparison"): that of a cluster or

the - mainly unacknowledged - author of many important medical entries in the Encyclopédie, and, perhaps most famously, Paul-Joseph Barthez (1734-1806) in the later eighteenth century.

31 This text first appeared in Latin in 1751 (supposedly in Erlangen - actually in Berlin) under the title Dissertatio inauguralis metaphysica de universali naturae systemate, with the pseudonym Dr. Baumann; Maupertuis translated it into French in 1754, now with a more explicitly 'biological' title, as Essai sur la formation des corps organisés (with a pseudonymous translator's name); it was later included in his 1756 Euvres under the title Système de la nature.

32 "I have customarily used the term 'circle' to convey that a part, even if it receives blood by means of the general circulation, as occurring in the largest vessels, nevertheless has a particular circulation, depending on whether it is in action or not; the other parts which 'feel' this action, belong to its department, its circle, etc.” [Bordeu 1818, I, p. 187].

33 "The least part should be considered as 'a body apart', so to speak. True, it acts by means of the general circulation, but it is as distinct as the system of blood vessels is distinct from the chiliac 
swarm of bees. As the beeswarm arguably represents the single most condensed expression of the animal economy in Montpellier vitalism, it is worth quoting it at length:

Might I make use of a comparison which, however rough, may be useful?

I compare the living body, in order to properly estimate the particular action of each part, to a swarm of bees which cluster together [se ramassent en pelotons], and hang from a tree like a bunch of grapes; I find the image suggested by an ancient author, that one of the lower organs was an animal in animali, ${ }^{34}$ to be quite helpful. Each part is, so to speak, not quite an animal, but a kind of independent machine [machine à part] which contributes [concourt] in its way to the general life of the body.

Hence, following the comparison to a bee swarm, it is a whole stuck to a tree branch, by means of the action of many bees which must act in concert to hold on; some others become attached to the initial ones, and so on; all concur [concourent] in forming a fairly solid body, yet each one has a particular action, apart from the others; if one of them gives way or acts too vigorously, the entire mass will be disturbed: when they all conspire to stick close, to mutually embrace, in the order of required proportions, they will comprise a whole which shall endure until they disturb one another.

[Bordeu 1818, I, p. 187]

Bordeu then tries to spell out the literal correspondence of the image: the interconnection of the bodily organs, the way each organ has its "district" and its "action"; importantly, he adds that "the relations between these actions, the resulting harmony, is what makes health" [ibid., emphasis S.K/C.W.]. Disturbance in this relation between the parts is what constitutes illness, of varying severity. In other texts, Bordeu (as well as other Montpellier vitalists, notably Ménuret and Henri Fouquet) spoke in related terms of the different organs not as mere 'parts' but as 'little lives.' In his work on 'chronic illnesses,' Bordeu does not specifically use the beeswarm image but presents three "theorems" which describe the living body as "an assemblage of several organs, each of which live in their own way, which feel more or less, and move, act or rest in fixed times; for, following Hippocrates, all parts of animals are animate" [Bordeu 1818, II, p. 829]. He also explains that the organs are "expansions of the

vessel system, or as the circulation of the lung and the liver are from what occurs in ordinary large vessels” [Bordeu 1818, I, p. 187].

34 [One might say 'has a life of its own.'] Bordeu notes, regarding the expression animal in animali, that the ancients already held that each part of the body had a particular form of action [Bordeu 1818, I, p. 188]. Fouquet refers to Galen on the theme of each organ having its own "life," and adds that other ancient authorities, including Plato, compared the liver, among other organs, to an animal contained in another animal; an image that Van Helmont applied to the uterus [Fouquet 1802, p. 78, n. 4]. Cf. [Rey 1997, pp. 137-138]. Harvey uses the same expression, for the womb, in his work on generation: "as if the Womb were Animal in Animali, one living creature in another; and had a peculiar independent motion of its own" (the expression is also used in the original Latin text) [Harvey $1653, \S 68$, p. 415]. Diderot also speaks of a particular organ, the eyes, as "un animal dans l'animal" [Diderot 1975-, vol. 17, p. 500] and then states more generally that man can be understood as "an assemblage of animals in which each one retains its peculiar function" [ibid., p. 501], describing the relation between organic parts in terms of 'sympathy.' 
nerves," and - in terms already familiar to us - defines what he calls "general life" as "the sum of all the particular lives"; "all of the parts are both causes, principles and final causes” [Bordeu 1818, II, p. 829]. The parts of an organism are constituted by a stable interaction, not just of inanimate parts but of 'lives,' that is, of organs considered as lives, like individual bees in the collective swarm.

Ménuret describes movement and sensation as two basic properties which exist in modified forms in every organ; "they give rise to a corresponding number of particular lives, the whole of which, in concert [concours] and mutual support, form the general life of the body"; Fouquet says that "each organ senses or lives in its own way, and the agreement [concours] or sum of these particular lives comprises life in general, just as the harmony, symmetry and arrangement of these little lives comprises health" [Ménuret 1765b, Enc. XI, 361b; Fouquet 1765, Enc. XV, 42b]. In his article “Observation,” Ménuret refers to both Bordeu's and Maupertuis' works, noting that they were published in 1751, but that Bordeu's has priority, having been authored in 1749. He mentions the beeswarm and Bordeu in order to emphasize that life in the body occurs, or is best described as, a "connection of actions" (liaison d'actions). After criticizing earlier medical commentators for failing to notice the interconnectedness of organic phenomena in the living body, he makes explicit use of our key metaphor, and explicitly praises the two earlier authors for having first introduced it:

One could, following these authors, compare man to a flock of cranes which fly together, in a particular order, without mutually assisting or depending on one another. [In contrast,] The Physicians or Philosophers who have studied and carefully observed man, have noticed this sympathy in all animal movements - this constant and necessary agreement in the interaction of the various parts, however disparate or distant from one another; they have also noticed the disturbance of the whole that results from the sensory disagreement of a single part. A famous physician (M. de Bordeu) and an illustrious physicist (M. de Maupertuis) likewise compared man, from this luminous and philosophical point of view, to a swarm of bees which strive together to hang to a tree branch. One can see them pressing and sustaining one another, forming $a$ kind of whole (une espèce de tout), in which each living part contributes in its way, by the correspondence and direction of its movements, to sustain this kind of life of the whole body, if we may refer in this way to a mere connection of actions (liaison d'actions) ${ }^{35}$

[Ménuret 1765a, pp. 318b-319a (emphasis S.K/C.W.)].

Without wanting to read into this text metaphysical considerations which are foreign to it (whether issues of mereology, the idea of an ontology of relations, or that of structural realism), it is the case that in these discussions of "sympathetic relations" between parts (organs), the materiality of the relations is recognized. It is not

35 In her discussion of the political uses of the metaphor of flocks of cranes, Kalff reminds us that Aristotle had listed, in addition to bees, wasps and ants, cranes as social animals [Kalff 2014, p. 437]. Wallmann notes that in Bodin, bees and cranes are also used together as examples, but in a monarchical sense, more or less opposite to the vitalist usage, while Kalff cites various Renaissance authors for whom the crane was a model of republican equality [Wallmann 2017, p. 147]. 
just a matter of different entities communicating with one another in the void, so to speak. In this passage in particular, the cranes are presented as merely contiguous: they fly together "without mutually assisting or depending on one another," which is to say, without crucial interconnecting phenomena such as 'sympathy.' Interestingly, Ménuret uses more mechanistic - or mechanism-friendly - language than his peers do, speaking of connections, movements, pressure, support, agreement in relation between parts, and so on. Whether the term used is 'metaphorical,' like the beeswarm, 'technical,' like that of 'organic sympathies,' or somewhere in between the two, like the 'circle of action,' we can see that Ménuret and Bordeu are trying to articulate a structural, relational concept of interaction among living parts ("lives") which does not rely on strictly linear causality - in other words, that is not strictly mechanistic, although (contrary to claims by some earlier interpreters who rely on a somewhat facile opposition between mechanism and vitalism) it is also not anti-mechanistic: one might see their focus on 'structure' as a kind of 'expanded mechanism.' This is also shown by the frequent usage of the Hippocratic maxim, "everything concurs, consents and conspires together in the body" [Ménuret $1765 \mathrm{~b}, 363 \mathrm{~b}]^{36}$ The forces and actions of the animal economy are too intimately intertwined to be quantified according to purely mechanical laws of force and motion.

Returning to the grappe or groupe d'abeilles, we are tempted to ask what kind of concept it is; it is an 'image,' of course, but one which its authors clearly intend as encapsulating their speculative and practical efforts. Bordeu himself is aware of the difficulty and asks "to be allowed a metaphor," when dealing with forces that govern "a thousand singular motions in the human body and its parts," given that "we do not even know which terms to use to describe certain motions in plants or properties of minerals." He admits at the end of this passage that he can only provide "a way of conceiving things [une manière de concevoir les choses], metaphorical expressions, and comparisons" [Bordeu 1818, I, p. 163]. The status of metaphors in scientific investigation has gone through considerable changes (most prominently due to Mary Hesse's insistence on their importance); leaving outside the outright denial that metaphors have any 'purchase' on scientific reality, one can summarily distinguish between three views on their role in science, in increasing strengths: (i) they play a weak heuristic role, (ii) they contribute to theory construction and thus play a stronger heuristic role, and (iii) they are equivalent to models, which contain various possible analogies to be investigated. ${ }^{37}$ We might say that for Bordeu et al., the beeswarm is a scientific metaphor in sense (ii); for Diderot, it reaches the status of an ontological claim itself, within which further theories can be investigated, hence like sense (iii).

36 'Sympathy' is often used in connection with terms such as 'cohesion,' 'conspiration,' and 'consensus' in these texts.

37 This useful way of distinguishing different senses of metaphor in science is suggested in [Petkov 2015], referring respectively to Ortony, Black, and Hesse. 
Ludwig Feuerbach understood Leibniz's theory of monads (as nested individuals) on the model of the beehive - an image which is not used by Leibniz himself. In his 1837 Darstellung, Entwicklung und Kritik der Leibniz'schen Philosophie (Presentation, Development, and Critique of the Leibnizian Philosophy), he wrote that the body, which the monads "bring together and hold together," is the beehive, while the dominant monad is the queen or mother bee. Building on the kind of organismic intuition we have seen developed in Bordeu, Maupertuis, and Ménuret (none of whom credit Leibniz in those passages - although Bordeu does so elsewhere ${ }^{38}$ ), Feuerbach adds that the bees "do not live in such a loose connection as the beasts of a herd; they constitute one whole; every individual bee is to be seen as just one member of this organism, having only a partial life [Theilleben], a particular function, like an organ in my body"; yet every bee is nevertheless "an individual in itself, a particular being that stands on its own legs" [Feuerbach 1837, p. 86, cit. in Smith 2011, p. 140]. ${ }^{39}$

Related images of organic unity can be found in non-vitalist authors of the period, but not as sharply focused as the beeswarm in Bordeu and Ménuret. Thus, the wellknown Geneva naturalist Charles Bonnet reintroduced sociopolitical language to describe the tree as an autonomous "organic society": "an assemblage of a multitude of subordinate organic productions, tightly connected to each other, all participating in a shared life and needs, yet each of which also has its own life, needs and functions" [Bonnet 1769, p. 164]..$^{40}$ He continues by describing how all of these individuals work toward the "common good" of this society, that is, the tree, while at the same time seeking out their own personal good - this seems to echo Mandeville, but as we noted earlier, in this respect Mandeville was only taking up, albeit with much more talent and biting irony, a model (private vices/public benefits) that was in fact there in most beekeeping texts from the beginning. Across the Channel, Samuel T. Coleridge wrote, in his unfinished "theory of life," of a "tendency to individuation" characteristic of the way life unites the parts of a body, life being defined "as the principle of individuation, or the power which unites a given all into a whole that is presupposed by all its parts" [Coleridge 1848, pt. III, p. 42], but in fact stresses this "élan vital"-like character of striving and unification more than the Montpellier vitalists do.

The understanding of organic individuality in the vitalist authors surveyed above does not treat such individuality (also known as 'specific modes of organization') as a thing but as a 'system,' a dynamic relation between individual vital centers (the little 'lives') which are interrelated by means of 'sympathy,' 'consensus,' 'conspiration,' and so on, that is, various forms of reciprocity, in a 'circle of action.' As Elisabeth Wallmann

38 Bordeu named monads (along with Buffon's organic molecules) in his list of the main "hypotheses on the elements of bodies" [Bordeu 1818, II, p. 925]. The "fortunes" of Leibniz's monadology read as a kind of biological theory in the eighteenth century is another story.

39 Thanks to Justin E.H. Smith for this reference.

40 See also: [Citton 2006, ch. 6, on individuation]. 
notes, while naturalists such as Réaumur or the writers of beekeeping manuals defined the swarm as "the temporary and highly unstable formation of a collective of bees as they searched for a new home," medical theorists such as our vitalists emphasized instead "the way in which the swarm seemed to form a new bodily unity irreducible to the insects that formed it. The swarm-body, they argued, mirrored the economy of the human body, similarly composed of seemingly independent parts that became one with the body as a whole” [Wallmann 2017, p. 117]. But authors like Richard Bentley who feared the materialist implications of the beeswarm - indeed its specifically vital-materialist implications - may have felt vindicated in the end because after this vitalist treatment in which the beeswarm lacks disturbing ontological and/ or political overtones, its appropriation and transformation at the hands of Diderot, in what many consider to be his masterpiece, Le Rêve de D'Alembert, is a key moment of radical materialism.

\section{Unsystematic Vitality: Diderot's Vital-Materialist Beeswarm}

First, a brief introduction to the context in which our core image appears in Diderot's work. Le Rêve de D'Alembert contains, in an unusual, experimental prose form, some of Diderot's most important thinking at the intersection between metaphysics and the newly emerging life sciences. The work remained unpublished for many years after his death, and was given as a gift in manuscript to Catherine the Great. It is, famously, composed of three dialogues, each of which features characters named after real, living figures of the time. The first dialogue, between Diderot and Jean Le Rond d'Alembert, covers traditional philosophical issues such as self and world, matter and thought, the existence of God, sensation and the true properties of objects. The second, longest and central dialogue involves the somnolent D'Alembert, the doctor Bordeu (who, in an earlier draft, Diderot had named La Mettrie), and Mlle de Lespinasse. It contains the image of the beeswarm, which belongs to the part in which Lespinasse reports D'Alembert's apparently incoherent dream utterances. The third dialogue is shorter again, and involves only Doctor Bordeu and Mlle de Lespinasse discussing certain issues from the earlier dream discussions, including monsters considered as both biological and social problems, the relation between matter

and sensation, and the nature of biological reproduction with explicit attention to its sexual dimension.

The image of the beeswarm comes after a long description of chemical concepts which Mlle de Lespinasse reprises from D’Alembert's 'ravings.' This description concludes with a reference to a type of "unity" that "only exists in the animal," a type of "action and reaction" which binds the parts together. At this point, D'Alembert cries out (or rather, it is reported that he cried out): 
Have you ever seen a swarm of bees leaving their hive? [...] The world, or the general mass of
matter, is the great hive [...]. Have you seen them fly away and form a long cluster of little
winged animals, hanging off the end of the branch of a tree, all clinging on to each other by
their feet? [...] This cluster is a being, an individual, some sort of animal [...]. If one of these
bees decides to pinch somehow the bee it is clinging onto, do you know what will happen?
[...] [T] his one will pinch the next one; [...] as many pinching sensations will arise throughout
the cluster as there are little animals in it; [...] the whole cluster will stir, move and change
position and shape [...]. [S] omeone who'd never seen the formation of a cluster like that
would be tempted to think it was a single animal with five or six hundred heads and a thou-
sand or twelve hundred wings. ${ }^{41}$
[Diderot 1975-, vol. 17, p. 120]

Diderot had actually used this image, but in much more summary fashion, in his Pensées sur l'interprétation de la nature, some thirteen years earlier, in 1753. There, commenting on Maupertuis' Système de la nature in the final sections of the work, he reflected on the mechanisms of generation, how 'information' is conveyed in the seminal fluid, how the elements retain a kind of 'memory,' and so forth. Mentioning the equally evocative image of the polyp, Diderot added that these "may be compared to a cluster of infinitely small bees which, as they only retain a living memory of one position, would cling to one another and remain in that situation, in accordance with the position most familiar to them" [Diderot 1975-, vol. 9, p. 80].

Diderot takes over from Bordeu the idea that individual organs 'live' in the organism like tiny animals composing one larger animal, but with a newer meaning, in which the distinction between contiguity and continuity is central. Indeed, as Rudy Le Menthéour observes, the difference between a hive and a swarm for a thinker like Diderot is that the relation between parts in the former is merely contiguous, whereas in the latter it is continuous. François Pépin emphasizes that this new model in which external parts are assimilated together (when the legs of the various bees join together to form "a single animal") is also, crucially, a chemical one [Le Menthéour 2009, p. 211; Pépin 2011, p. 141]. The life of the animal, "l'animal entier," is the composite of the life of each organic component, interacting in a relation of "sympathy" (the modernized form of the Hippocratic sympathia panta, used in these texts as a technical term for nervous interconnection), which sometimes is not dependent on any center, any 'controller' at all: “these are sensing and living organs, coupling, sympathizing and concurring towards the same goal, without the participation of the whole animal" [Diderot 1975-, vol. 17, p. 501]. (On the political side, Mandeville, too, was not concerned with the role of the monarch as a possible central or centralizing force that keeps the hive together, even if the latter was a monarchical community. For him the collection of private interests is what keeps it from falling apart.)

41 For discussion, see: [Dieckmann 1938, pp. 86-87]. 
This raises the question of the unity of the organism (in the Reve, the unity of the self, which Mlle de Lespinasse worries about - to which the reply, via the character Bordeu, is precisely a doctrine of organismic unity, that is, you are yourself because of the individuality of your body or organisation). After all, if an organism is a sum of many lives, whether this is an additive or one that involves qualitative shifts, where is the limit? This is another one of the difficult questions that neither Diderot nor Bordeu - both of whom pose it - resolves to anyone's satisfaction, including their own. One recalls that Bordeu introduced the image of the beeswarm as a metaphor of organic unity, and Diderot, although he expands on it and adds other metaphors for the nervous system including the spider's web and the harpsichord (for the vibrating 'strings' of the nervous system) does not present it as anything other than that.

Diderot brings together a more mechanistically oriented account of a structural relation between solid parts (from Albrecht von Haller), the more holistic sense of an integrated network of sensibility/sympathy (from Bordeu and others) and various other theories of organic matter concerning what we might call 'vital minima,' that is, the minimal constituents of organic life which are themselves "alive" and possessed of animate properties. Contrasting with theories such as Haller's, he collapses any residual dualist distinction between irritability and sensibility (which in Haller and other authors had served to preserve a concept of soul): "Generally, in the animal and in each of its parts - life, sensibility and irritation” [Diderot 1975-, vol. 17, p. 449]. Specifically as regards the beeswarm metaphor, one can see that Diderot is both nudging it in the direction of a different register, a different discursive space, but also, emphasizing holistic properties even further. Where Maupertuis and Bordeu were indeed reflecting on the nature of 'wholes,' Diderot is willing to state that the world itself is the hive (or swarm), in a kind of suspension of boundaries. Diderot would doubtless have endorsed this statement of Henri Bergson, regarding the "things of life": "who can say exactly where individuality begins and ends, whether the living being is one or many... In vain we force the living into this or that one of our molds" [Bergson 1911, p. x].

Up until now, we have treated the beeswarm metaphor primarily in its biomedical context, with some limited comparative reflection on its sociopolitical usage. But, as Diderot's case highlights, this metaphor plays other roles as well. As we saw with Clarke, Bentley and others above, the swarm could be a problematic image inasmuch as it conveyed dispersion rather than unity; as such, it is no coincidence that it was associated with materialism, for a major objection to materialism, in its treatment of life, body, and person, is the seeming absence of any 'center' or 'self' within the system of living parts. Sometimes, this is presented as disturbing, as dangerous Epicureanism; sometimes, as a fascinating feature of organic nature overall, as in Johann Wolfgang von Goethe's reaction: “Countless animals in a drop, that moved among each other with unspeakable agility and shortly gathered themselves 
together into a thick, swarming cluster." 42 Indeed, as their fascination with the image of the beeswarm shows, a number of materialists - call them 'vital materialists' - are deeply concerned with providing an account of the organism or body as something more than a set of interlocking, solid parts, although this "something other or more" is not understood as either 'soul' or 'vital force.' We might say that the issue is not just organismic unity but also biological individuality.

Additionally, this opens onto what contemporary researchers will call 'swarm intelligence,' that is, the question again of unity in multiplicity, but posed no longer in terms of life but of mind; it is actually not easy to historically demarcate arguments for organic unity in terms of life (cohesion, sympathy, chemistry, etc.) from arguments in terms of mind, which do become more visible in the nineteenth century and beyond. ${ }^{43}$ Kate Tunstall has suggested that Diderot's usage of the beeswarm illustrates "the way in which body parts cooperate and perform actions without the need for an immaterial soul" [Tunstall 2016, p. 218]. That is, it is not just that the body can think - a more garden-variety materialist claim - but that what she calls, loosely referring to some ideas in cognitive science, "embodied thinking" takes place throughout the body "and in the relationships between bodies": swarm intelligence is "extended" as well as "embodied" [ibid., p. 205]. A similar description, in this case taking eighteenth-century vitalism (very broadly construed) as its object, is given by Catherine Packham: vitalism "dethrone[ed] the mind from its assumed role of reasoned governance of the body, and by envisioning, instead, a body capable of automatic and autonomous, if unconscious and instinctual, self-direction and selfpreservation" [Packham 2012, p. 19]. ${ }^{44}$

While it is interesting, and surely fruitful to conceive of the beeswarm in Diderot as a model of self, of distributed cognition, of plural selfhood, it seems to us that what Stephen Gaukroger referred to as the "unsystematic vitality" [Gaukroger 2005] of a beeswarm is being used as a true model of natural processes (rather than as a mathematical one).

42 Goethe's notes on infusoria experiments (1785-1786), May 11, $\mathrm{n}^{\circ}$ 9, in Schriften zur Naturwissenschaft, I.10, p. 39, quoted in [Goldstein 2011, p. 9].

43 The case of Leibniz seems unusual, in that he explicitly distinguished aggregates from organisms ("corporeal substances") in terms of mind: "a corporeal substance [...] is one per se, and not a mere aggregate of many substances, for there is a great difference between an animal, for example, and a flock"; it "is either a soul or something analogous to a soul, and always naturally activates some organic body, which, taken separately, indeed, set apart or removed from soul, is not one substance but an aggregate of many, in a word, a machine of nature." (Untitled text from May 1702, G IV, pp. 395-396; translation under the title "On Body and Force, Against the Cartesians" in [Leibniz 1989, pp. 252-253]. Thanks to Sarah Tropper for this reference.)

44 Here, Packham is anticipating Sheehan and Wahrman's description of a kind of joint constitution of the self-organization concept, in biology and in society. 


\section{Conclusion: Swarm Intelligence and Superorganisms}

What type of organizational model is the beeswarm? Aside from the variety of political and/or mathematical usages of the beeswarm which were not central to our story, we have focused on how this image functions as a way of articulating and explicating the twin motifs of organic (or organismic) unity and biological individuality. While Diderot could be seen as a culmination, as the most complex treatment of the beeswarm (and certainly of its explicit encounter with materialism), it is also possible to extract different, equally viable models from the other vitalist treatments of the swarm. For instance, as we discussed, Ménuret's version gave a greater role to the properties of the parts (= lives=organs), in a sense closer to what we might term componential analysis. This should be emphasized, as it is not generally an intellectual attitude associated with 'vitalism.' For Ménuret, there is a sense in which, aside from the existence of higher-level properties like health (or sickness), "the parts remain what they were," to borrow a phrase from the early-twentiethcentury emergentist Samuel Alexander. ${ }^{45}$ While Buffon is not to be counted among the small number of 'beeswarm theorists' that we examine here, unlike Bordeu and Diderot in particular, he too recognizes the phenomenon of emergent order, understood in the sense that (not in Buffon's words) rules of interaction between bees are, inseparably, what makes an individual bee a bee, and what makes the hive a hive [Epstein 1999, p. 55]. Much later, at the end of the nineteenth century, D'Arcy Wentworth Thompson dedicated a whole chapter of his sui generis work On Growth and Form to the construction of the regular cells in the beehive (the hexagonal structure has now been shown to be optimal: [Hales 2001]). To him, physical forces condition the shape of organisms and the geometry of the hive. The "beautiful regularity of the bee's architecture" is not due to apian ingenuity or instinct, or to the "geometrical forethought of the bees" but rather to "some automatic play of the physical forces" [Thompson 1992, pp. 132, 138].

Yet, however, 'emergent(ist)' the order of the beeswarm may be - and here, the difference between swarm and hive seems relevant - ontologically, it is entirely material, without 'spooky' features. Not only is the order not 'top-down,' but there are no spiritual or otherwise immaterial properties involved (unlike, say, what was always claimed about the 'entelechies' of later neo-vitalism). The unity of the animal described in the above texts is not the property or the 'doing' of a central self or controller:

45 Alexander discusses how "physiological complexes of a sufficient complexity carry mind or consciousness," yet "in the complex which thus acquires a new quality the parts retain their proper character and are not altered. The physiological elements remain physiological [...] The water in our bodies remains water still [...] the parts remain what they were" [Alexander 1927, p. 370 (emphasis S.K/ C.W.)]. 
There is no central, or 'top-down,' control over individual behavior in agent-based models. Of course, there will generally be feedback from macrostructures to microstructures, as where newborn agents are conditioned by social norms or institutions that have taken shape endogenously through earlier agent interactions. In this sense, micro and macro will typically coevolve. But as a matter of model specification, no central controllers or other higher authorities are posited ab initio.

[Epstein 1999, p. 42]

It is in this sense that complex structures emerge from the interaction of simpler agents, to the delight of eighteenth-century vitalists, as well as embodied roboticists, behavioral economists, and other researchers nowadays.

And here, our efforts to keep the political resonance of the swarm concept separate from its more 'naturalistic' dimensions can seem futile if we reflect on the way that swarms in some strands of contemporary thought present a "political paradox between 'control and emergence, sovereignty and multiplicity"”; "swarms organize the multiple into a relational whole - and one in which the collective is exactly defined by 'relationality"' [Parikka 2010, p. 47]. ${ }^{46}$ Here, Diderot's choice of the swarm over the hive, following the vitalist example, is telling: the swarm is "a community without a leader, where agency is distributed among equal, indistinguishable parts rather than located with a queen that can easily be singled out by the observer" [Wallmann 2017, p. 145]. In fact, in an expression of dynamism and processuality that Diderot doubtless would have endorsed, the term "swarm" is used to describe both the community of bees and the process by which it becomes divided, much like cell division in any living organism (growth and reproduction) extends the more informal body of the bees (genus) in space but also reproduces/duplicates the original swarm.

In a 1943 essay on Bergson, Georges Canguilhem refers to a distinction derived from Heinrich Rickert's 'philosophy of life,' which is both familiar to us and subtly different: between 'aristocratic' and 'democratic' tendencies in biology, where the latter are based on the principle of vital economy, and are deterministic (life is reducible to a mechanical and material phenomenon, and tends only to its own preservation); in contrast, the aristocratic tendency (Canguilhem mentions Friedrich Nietzsche) understands life as self-overcoming, as an instrument of hierarchical creation [Canguilhem 2007]. The swarm as discussed here indeed tends to be a more 'republican,' 'cooperative,' and 'emergent' affair. Now, our concern, unlike that of Giacomo Domenico Maraldi or Réaumur in earlier centuries, is not the role of the queen or the drone, but, rather, what sort of organizational whole the beeswarm is (or is meant to model). What Sheehan and Wahrman say of Diderot is actually true more broadly of numerous theorists of biological (or at least embodied) individuality of the period: "What in Bernard Mandeville had embodied the paradoxes of complex social systems, in Diderot embodied those of natural ones" [Sheehan and Wahrman 2015, ch. 4].

46 Parikka discussing the ideas of Eugene Thacker. 
For Bordeu and his vitalist peers, the point was that bees in a swarm are like little lives composing a greater life; as Joshua Epstein puts it in a non-vitalist contemporary context, "the bee's interaction rules are what make it a bee - and not a lump. When [...] you get these rules right - when you get 'the individual bee' right - you get the hive, too" [Epstein 1999, p. 55]. To his earlier remark on the rules of interaction that govern bees and their hive, Epstein adds that in operational terms, "bee" might be defined as "that $x$ that, when put together with other $x$ 's, makes the hive (the 'emergent entity')" [ibid.]. What about the individuality of this larger collective? In what sense is a swarm an actual individual? This is what is referred to nowadays as the 'superorganism' concept, a term originally introduced in the early twentieth century by William Morton Wheeler, as a means of understanding how social insect collectives hold together. For Wheeler, a colony of social insects (although this could be extrapolated to other groups of animals, as is the case in current work on collective behavior) is properly identified as an organism, and not merely an analog of one: "The most general organismal character of the ant-colony is its individuality. Like the cell or the person, it behaves as a unitary whole, maintaining its identity in space, resisting dissolution and, as a general rule, any fusion with other colonies of the same or alien species" [Wheeler 1911, p. 310]. ${ }^{47}$ Building on this approach, Thomas Seeley describes the honey-bee colonies he studies as "superorganisms" because of their high degree of cohesiveness, made possible because each bee is free to move about the nest and exchange information with other members of the hive (through signals, such as the bee-dance, and cues) [Seeley 1989]. ${ }^{48}$ Other researchers speak of the "tightness of bee colonies" [Haber 2013, p. 197], and note that "animals often organize into groups that outperform the individuals that comprise them" [Feinerman 2018, p. 55]. In sum, bee (or ant, or termite) colonies are termed "superorganisms" because they exhibit many organism-like traits.

But extending the focus on the beeswarm as model into the present also yields a slightly different result: while the approach we discussed above focuses on unity and interconnectedness of the small 'lives' as forming a larger individual life, another focuses on how tiny agents in interaction yield (or indeed, are), as Cavendish argued, "one Minde." Thus, one of the most prominent researchers into the neurobiology of bees has written about the beehive as a "thinking machine" [Seeley and

47 To this one can add ontogenetic and phylogenetic development, and that the colony displays the Weismannian division of germ plasm and soma [Mitchell 1995, p. 238]. It is probably no coincidence that Wheeler was also actively interested in holistic/organismic ideas at a more abstract level, including in his commitment to "emergent evolution" [Parikka 2010, p. 51].

48 This fits with Turner's celebrated work on termite mounds as part of the "extended physiology" of the termites. There is debate, however, as to whether these colonies constitute real biological individuals or not: for instance, superorganisms do not reproduce (Haber). But beekeeper breeding plans seem indeed to focus on colony-level traits, not genetic traits of individual queens. 
Levien 1987]; ${ }^{49}$ equally influential, the researcher in social insect physiology J. Scott Turner even credits Bordeu but straight away adds a notion of intelligence:

Emergent intelligence traces its roots to the venerable observation that intelligence seems to crop up in unusual contexts. The most common of these unusual contexts is the social insect colony, and its emergent intelligence was articulated as early as the end of the eighteenth century by Theophile de Bordeu, who noted the seemingly intelligent and coordinated behavior of the bee swarm.

[Turner 2016]

For Turner, Bordeu's question is less about organismic unity, as we described above, and more about how a swarm acts intelligently, even though there was no brain or other evident "specifier" to create it. This is not a brand-new idea: "Swarming was early on described as a peculiar group behavior that was of interest to entomologists and researchers of social insects. [...] for them, it represented a weird kind of organization that seemed to reside between instinct and intelligence" [Parikka 2010, p. 48]. This focus on the collective pattern of behavior of the bees as a kind of 'mind,' 'intelligence,' 'group cognition,' 'extended cognition,' and so forth (one thinks of Edwin Hutchins' influential study of life on a navy ship as a kind of giant brain in which the different individuals are like individual neurons [Hutchins 1995]) tends to take an increasingly abstract form, in which biological agents and their interactions become models, algorithms, and other objects of computation.

Bordeu's question (we might say the 'Bordeu-Diderot question') has remained alive until now, albeit in a less material form, given that the contemporary term for emergent intelligence is swarm intelligence, that is, the solving of cognitive problems by a group of individuals - typically, social insects - who pool their knowledge and process it through social interactions. Theories of swarm cognition or swarm intelligence emphasize that the individual bee (or ant, or termite) has vastly inferior cognitive capacities to the swarm as a whole; the latter has a richer cognitive repertoire because it inhabits a world full of more diverse cues and stimuli. Some researchers speak of 'nonconscious cognition' here, as collective action can take place in and through chemical signaling and other non-semantic modes of communication. Further, algorithms are now developed based on the intelligent behavior of bees (or ants), with names such as 'bee swarm optimization' or 'ant colony optimization' algorithms: these population-based techniques are used to find ideal ways of managing networks and other distributed systems, that is, "optimization research" [Bonabeau, Dorigo, and Theraulaz 1999, p. 7]. ${ }^{50}$

If the beeswarm stands for life (organism) in the first case, and mind (intelligence, cognition) in the second, both share a fundamentally distributed character -

49 Recall that at least one interpreter of the beeswarm in Diderot, Tunstall, read this image as pointing to a theory of extended and embodied mind.

50 The term 'swarm intelligence' was first used by Beni and Wang in a paper of that title published in 1989. 
in the latter case, as distributed cognition, that is, individual bees taken together as a collective are understood as forming a kind of brain, like Hutchins' navy ship. Bees (or ants in other discussions of swarm intelligence) are like individual neurons. As Georg Theiner and Tim O’Connor put it helpfully,

ants exhibit a 'neuron-like' behavior insofar as inactive ants have a low propensity to become spontaneously active, but can become excited by other ants with whom they come into contact [...]. Conversely, ants are prone to lapse back into inactivity if their activation is not sufficiently reinforced, and even exhibit a short refractory period (similar to neurons) before they can be reactivated - a mechanism which keeps the swarm from getting permanently 'locked' into an excitatory state.

[Theiner and O'Connor 2010, p. 90]

Now, this 'relational' quality of individual bees who only achieve their true potential in a collective unit can be characterized in a variety of ways. Not only does it allow of various sociopolitical, biological, metaphysical or cognitivist appropriations, as we have seen above; it can also be spelled out according to different theoretical vocabularies. In some hands, the beeswarm can also turn out to be Deleuzian, like Monsieur Jourdain, who wrote prose without knowing it. Thus Jussi Parikka argues that individual bees performing the 'bee dance' (as described in Karl von Frisch's pioneering work on bee communication, which showed how the orientation of the bee, its energy output, and the direction of the dance all communicate precise information about food sources) are not "representational entities" but "machinological becomings": they should be understood

in terms of their capabilities of perceiving and grasping the environmental fluctuations as part of their organizational structures [...] where the intelligence of the interaction is not located in any one bee, or even a collective of bees as a stable unit, but in the 'in-between' space of becoming: bees relating to the mattering milieu, which becomes articulated as a continuum to the social behavior of the insect community. This community is not based on representational content, then, but on distributed organization of the society of nonhuman actors. ${ }^{51}$

[Parikka 2010, p. 129]

Note that the 'algorithmic' approach is different, less speculative. If we compare Bordeu's beeswarm to that of swarm intelligence, of honeybee colony algorithms, one striking difference is that the latter is a model - in that sense closer to the mathematical obsession of Johann Samuel König, Réaumur, and D’Arcy Thompson. Granted, it is not the same mathematics at issue, but our point is simply to contrast the vitalist usage of the beeswarm in explicitly material terms - indeed as a form of organization, but one with concrete biochemical properties - with the more formal(istic) interest in the mathematics of hives and cells, or morphogenesis. In that sense, we would underline the fact that the eighteenth-century vitalist and materialist emphasis is on a type

51 Discussion in: [Hayles 2017, pp. 188-189]. 
of material agencement (obviously not "brute matter," given the emphasis on the concept of structure in the vitalist texts ${ }^{52}$ ) whereas models are dematerialized..$^{53}$

The beeswarm is a core metaphor and even model for organicism as a theory, with its emphasis on organs as 'lives,' not just mere parts, and indeed it is one of the standard metaphors of organism. However, it is in perpetual danger of fragmentation, as is also captured by the recurrent fears of the swarm as an image of reductive materialism and/or chaos. But the beeswarm, Janus bifrons, is inseparably an image of multiplicity and fragmentation, and an image of order and equilibrium, albeit less than the hive, with its appeal to those pondering the mathematics of built structures, or the algorithms of swarm intelligence. As a metaphor of identity itself, it also crisscrosses the boundaries of the social and the biological, as the core intuitions regarding unity or atomization reveal.

\section{Bibliography}

Alexander S. Space, Time and Deity: The Gifford Lectures at Glasgow, 1916-1918. Vol. 2. London, Macmillan, 1927.

Allen DS. Burning The Fable of the Bees: Cultural Poetics and the Incendiary Authority of Nature. In: Daston L, Vidal F, eds. The Moral Authority of Nature. Chicago, University of Chicago Press, 2003, 74-99.

Andersen K, Bos HJM. Pure Mathematics. In: Park K, Daston L, eds. The Cambridge History of Science. Vol. 3. Early Modern Science. Cambridge, Cambridge University Press, 2006, 696-707.

Arbuthnot J. The Congress of Bees: Or, Political Remarks on the Bees Swarming at St. James's. London, A. Moore, 1728.

Aristotle. History of Animals. Vol. 1, 1. Trans. Peck AL. Cambridge MA, Harvard University Press, 1965.

Aristotle. Politics. In: Barnes J, ed. The Complete Works of Aristotle. Vol. 2. Princeton, Princeton University Press, 1984.

Baine Campbell M. Busy Bees: Utopia, Dystopia and the Very Small. Journal of Medieval and Early Modern Studies 2006, 36 (3), 539-560.

Beni G, Wang J. Swarm Intelligence. In: Proceedings of the Seventh Annual Meeting of the Robotics Society of Japan. Tokyo, 1989, 425-448.

52 In his fascinating programmatic article in the Encyclopédie on the notion of "animal economy," the vitalist physician Ménuret de Chambaud defines the latter term as "l'ordre, le méchanisme, l'ensemble des fonctions \& des mouvemens qui entretiennent la vie des animaux" [Chambaud 1765b, 362a].

53 A recent revival of the bee trope in terms of "knowledge-gathering," "honeycombs of knowledge," speaks of the "revolt of the bees" but in a rather non-revolted way [Levy and Squire 2005] and, indeed, also more dematerialized. Our analysis is different, as the essays collected in the aforementioned volume take beehives and paper hives (e.g., archives and libraries) as utopias of memory storage, also related rather impressionistically to contemporary usage of beehive ideas in art and architecture. 
Bentley R. The Folly and Unreasonableness of Atheism. London, Printed by J.H. for H. Mortlock, 1693.

Bergier NS. Examen du matèrialisme ou rèfutation du système de la nature. Vol. 1. Paris, Humblot, 1771. Bergson H. Creative Evolution. Trans. A. Mitchell. New York, Henry Holt, 1911.

Bloch 0. Sur les premières apparitions du mot 'matèrialiste'. Raison présente 1978, 47, 3-16, DOI: 10.3406/raipr.1978.1945.

Bloch O. Matière à histoires. Paris, Vrin, 1997.

Blum C. On the Uses of Bees. In: Yolton JW, Brown LE, eds. Studies in Eighteenth-Century Culture. Vol. 18. East Lansing, Michigan, Colleagues Press, 1988, 3-5.

Bonabeau E, Dorigo M, Theraulaz G. Swarm Intelligence: From Natural to Artificial Systems. Oxford, Oxford University Press, 1999.

Bonnet $C$. Palingènèsie philosophique ou Idèes sur l'ètat passè et sur l'ètat futur des ètres vivans. Vol. 1. Geneva, Claude Philibert, Barthelemi Chirol, 1769.

Bonnet C. Considérations sur les corps organisés. Paris, Fayard, 1985 [1762].

Bordeu TD. OEuvres complétes, précédées d'une notice sur sa vie et ses ouvrages par Monsieur le chevalier de Richerand. Vol. 2 . Paris, Caille et Ravier, 1818.

Bouchard F, Huneman P, eds. From Groups to Individuals: Evolution and Emerging Individuality. Cambridge, MIT Press, 2013.

Boyle R. The History of Fluidity. In: Birch T, ed. The Works of Robert Boyle. Vol. 1. London, J, Rivington F et al., 1772, reprint, Hildesheim, Georg Olms, 1965, 378-400.

Brewer B. The Sterility of Abundance: Marcela and Grisostomo in the Golden Age. In: Boyd S, O'Reilly T, eds. Artifice of Invention in the Spanish Golden Age. Abingdon, Routledge and the Modern Humanities Research Association, 2014, 33-44.

Brown GI. The Evolution of the Term “Mixed Mathematics." Journal of the History of Ideas 1991, 52 (1), 81-102.

Buffon GLLD. Histoire Naturelle. Vol. 4. Paris, Imprimerie royale, 1753.

Butler C. The Feminine Monarchie, or the Historie of Bees. Oxford, J. Barnes, 1609.

Campana J. The Bee and the Sovereign? Political Entomology and the Problem of Scale. Shakespeare Studies 2013, 41, 94-113.

Campana J. The Bee and the Sovereign (II): Segments, Swarms, and the Early-Modern Multitude. In: Cefalu P, Kuchar G, Reynolds B, eds. The Return of Theory in Early-Modern Studies. Vol. 2. Basingstoke, Palgrave Macmillan, 2014, 59-79.

Canguilhem G. Aspects du Vitalisme. In: Canguilhem G: La Connaissance de la Vie. Revised. Paris, Vrin, 1965, 83-100.

Canguilhem G. Commentaire au troisième chapitre de L'Évolution créatrice. In: Worms F, ed. Annales bergsoniennes. Vol. 3. Bergson et la Science. Paris, PUF, 2007, 113-160.

Cascardi AJ. Cervantes, Literature, and the Discourse of Politics. Toronto, Toronto University Press, 2012.

Cavendish M. Natures Pictures Drawn by Fancies Pencil to the Life. London, J. Martin and J. Allestrye, 1656.

Cavendish M. Observations upon Experimental Philosophy. O’Neill E, Ed. Cambridge, Cambridge University Press, 2001 [1666].

Cavendish M. Sociable Letters. Fitzmaurice J, Ed. Abington, Routledge, 2012.

Cayrou G. Le français classique. Lexique de la langue du dix-septième siècle. Paris, Didier, 1948.

Cervantes De Saavedra M. The History and Adventures of the Renowned Don Quixote. Trans. Smollett T. Vol. 2. London, A. Millar, 1755.

Citton Y. L'Envers de la Liberté. L'invention d'un imaginaire spinoziste dans la France des Lumières. Paris, Éditions Amsterdam, 2006.

Clarke S. A Letter to Mr. Dodwell. London, Knapton, 1731. 
Coleridge ST. Hints Towards the Formation of a More Comprehensive Theory Of Life. Watson SB, Ed. London, John Churchill, 1848.

Daubenton LJM. Histoire naturelle. In: Daubenton LJM. Séances des Ecoles Normales, recueillies par des sténographes, et revues par les professeurs, nouvelle édition. Vol. 1. Paris, Imprimerie du cercle social, 1800, 92-97.

Daubenton LJM. Essaim. In: Diderot D, D’Alembert JR, eds. Encyclopédie ou Dictionnaire raisonné des arts et des métiers Vol. 5. Paris, Briasson, David, Le Breton \& Durand, 1757, reprint Stuttgart, Frommann, 1966, 994a-995b.

Day J. The Parliament of Bees, with their proper Characters... Being an Allegoricall Description of the Actions of Good and Bad men in these our Daies. London, William Lee, 1641.

Demeter T, Schliesser E. The Uses and Abuses of Mathematics in Early Modern Philosophy: Introduction. Synthese 2019, 196, 3461-3464, DOI: 10.1007/s11229-017-1670-y.

Diderot D. Euvres complètes. Vol. 9. Pensées sur l'Interprétation de la Nature. Varloot J, Ed. Paris, Hermann, 1975-.

Diderot D. CEuvres complètes. Vol. 17. Le Rêve de D’Alembert. Varloot J, Ed. Paris, Hermann, 1975-. Dieckmann H. Théophile de Bordeu und Diderots Rêve de D'Alembert. Romanische Forschungen 1938, 52 (1), 55-122.

Dinsdale J. The Modern Art of Breeding Bees, a Poem. London, J. Davidson, 1740.

Drouin JM. L'image des sociétés d'insectes en France à l'époque de la Révolution. Revue de Synthése 1992, 113 (3/4), 333-345.

Duflo C. Diderot et Ménuret de Chambaud. Recherches sur Diderot et sur l'Encyclopédie 2003, 34, 5, DOI: $10.4000 /$ rde.157.

Encyclopédie méthodique ou par ordre de matiéres. Vol. 8. Paris, Veuve Agasse, 1808.

Epstein J. Agent-Based Computational Models and Generative Social Science. Complexity 1999, 4 (5), 41-60, DOI: 10.1002/(SICI)1099-0526(199905/06)4:5<41::AID-CPLX9>3.0.CO;2-F.

Fairfax Withington A. Republican Bees: The Political Economy of the Beehive in Eighteenth-Century America. In: Yolton JW, Brown LE, eds. Studies in Eighteenth-Century Culture. Vol. 18. East Lansing, Michigan, Colleagues Press, 1988, 39-77.

Feinerman O. Leadership during Cooperative Transport by the Longhorn Crazy Ant. In: Gissis SB, Lamm E, Shavit A, eds. Landscapes of Collectivity in the Life Sciences. Cambridge MA, MIT Press, 2018, 55-65.

Feuerbach L. Darstellung, Entwicklung und Kritik der Leibnitz'schen Philosophie. Ansbach, C. Brügel, 1837.

Fouquet H. Sensibilité, Sentiment (Médecine). In: Encyclopédie. Vol. XV. Paris, Briasson, 1765, 38-52.

Fouquet H. Discours sur la Clinique. Montpellier, Izar \& Ricard, an XI, 1802.

Fraser HM. Beekeeping in Antiquity. London, University of London Press, 1931.

Freeman JA. Milton and the Martial Muse. Princeton, Princeton University Press, 1980.

Gambarotto A. Vital Forces, Teleology and Organisation: Philosophy of Nature and the Rise of Biology in Germany. Dordrecht, Springer, 2017.

Gaukroger S. The Collapse of Mechanism and the Rise of Sensibility: Science and the Shaping of Modernity, 1680-1760. Oxford, Oxford University Press, 2010.

Gaukroger S. 'The Enlightenment Revolt Against Rationalism': Critical Notice of Peter Hanns Reill, Vitalizing Nature in the Enlightenment. Australian Review of Public Affairs 2005, 26. (Accessed June 21, 2021, at http://www.australianreview.net/digest/2005/11/gaukroger.html.)

Godfrey-Smith P. Other Minds: The Octopus, the Sea, and the Deep Origins of Consciousness. London, Harper Collins, 2016. 
Goethe JW. Die Schriften zur Naturwissenschaft. Leopoldina-Ausgabe. 26 vols. Est. K. Lothar Wolf and Wilhelm Troll. Kuhn D, Engelhardt WV, Müller I, Eds, Weimar, Herman Böhlaus Nachfolger, 1947-2011.

Goldstein A. 'Sweet Science': Romantic Materialism and the New Sciences of Life. PhD thesis, Department of Comparative Literature, University of California, Berkeley, 2011.

Haber M. Colonies Are Individuals: Revisiting the Superorganism Revival. In: Bouchard F, Huneman P, eds. From Groups to Individuals: Evolution and Emerging Individuality. Cambridge, MIT Press, Vienna Series in Theoretical Biology, 2013, 195-217.

Hales TC. The Honeycomb Conjecture. Discrete Computational Geometry 2001, 25, 1-22.

Hancock J. Arguments to Prove the Being of God with Objections against it Answered. In: A Defence of Natural and Revealed Religion: Being a Collection of the Sermons Preached at the Lecture Founded by the Honourable Robert Boyle, Esq. Vol. 2. London, 1739, 197-258.

Haraway D. When We Have Never Been Human, What Is to Be Done? (Interview with Donna Haraway by Nicholas Gane). Theory, Culture \& Society 2006, 23 (7-8), 135-158, DOI: 10.1177/ 0263276406069228.

Hartlib S. The Reformed Commonwealth of Bees. London, G. Calvert, 1655.

Harvey W. Anatomical Exercitations Concerning the Generation of Living Creatures.

Trans. M. Llewellyn. London, Octaviani Pulleyn, 1653.

Hayles KN. The Cognitive Nonconscious and the New Materialisms. In: Ellenzweig S, Zammito J, eds.

The New Politics of Materialism. History, Philosophy, Science. London, Routledge, 2017, 181-199.

Hill T. The Arte of Gardening, [...]. London, E. Allde, 1608.

Hobbes T. Leviathan. Vol. 2. Malcolm N, Ed. Oxford, Clarendon, 2012.

Hoquet T. Buffon's Natural History: The Catalogue of Facts and the Temptation of System. In: Rey

AL, Bodenmann S, eds. What Does it Mean to be an Empiricist? Empiricisms in Eighteenth

Century Science. Dordrecht, Springer, 2018, 139-167.

Hutchins E. Cognition in the Wild. Cambridge, MIT Press, 1995.

Jacobs NA. John Milton's Beehive, from Polemic to Epic. Studies in Philosophy 2015, 112 (4), 798-816. Johach E. Der Bienenstaat: Geschichte eines politisch-moralischen Exempels. In: Von Der HA, Vogl J, eds. Politische Zoologie. Zurich, Diaphanes, 2007, 219-233.

Kalff S. Are Cranes Republicans? A Short Chapter in Political Ornithology. In: Enenkel KAE, Smith PJ, eds. Zoology in Early Modern Culture. Leiden, Brill, 2014, 437-459.

Le Menthéour R. De la ruche au polype: figures de l'organisation sociale. Dix-huitiéme siécle 2009, 41, 204-221, DOI: 10.3917/dhs.041.0204.

Leibniz GW. Die philosophischen Schriften. Vol. 7 . Gerhardt CI, Ed. Berlin, Weidmann, 1875-1890, reprint Hildesheim, New York, G. Olms, 1978.

Leibniz GW. Philosophical Essays. Trans. Ariew R, Garber D. Indianapolis, Hackett, 1989.

Levy A, Squire T, eds. The Revolt of the Bees: Essays by Anthony Grafton, Thomas Keenan, and Aaron Levy. Philadelphia, Slought Books, University of Pennsylvania Library, 2005.

Mancosu P. Philosophy of Mathematics and Mathematical Practice in the Seventeenth Century. Oxford, Oxford University Press, 1996.

Mandeville B. The Fable of the Bees, or Private Vices, Public Benefits. With a Commentary Critical, Historical and Explanatory by Kaye FB. Vol. 2. Oxford, Clarendon Press, 1924 [1714, 1729.

Mandeville B. A Treatise of the Hypochondriack and Hysterick Diseases, in Three Dialogues. Kleiman-Lafon S, Ed. Dordrecht, Springer, 2017, 1st ed. 1711, revised ed. 1730.

Maraldi GF. Observations sur les abeilles. Histoire de l'Académie royale des sciences. 1712. Paris, Imprimerie Royale, 1731, 297-331.

Marx K. Economic and Philosophic Manuscripts of 1844. Moscow, Progress Publishers, 1959 [1932].

Maupertuis PLMD. Système de la nature. Essai sur la formation des Corps organisés. In: Maupertuis PLMD. Euvres. Vol. 2. Lyon, Bruyset, 1756, 139-168. 
McLaughlin P. Naming Biology. Journal of the History of Biology 2002, 35, 1-4.

Ménuret De Chambaud JJ. Observation (Gram. Physiq. Méd.). In: Encyclopédie ou Dictionnaire raisonné des sciences, des arts et des métiers. Vol. 11. Paris, Briasson, 1765a, 313-321.

Ménuret De Chambaud JJ. Economie Animale (Médecine). In: Encyclopédie ou Dictionnaire raisonné des sciences, des arts et des métiers. Vol. 11. Paris, Briasson, 1765b, 360-366.

Merrick J. Royal Bees: The Gender Politics of the Beehive in Early-Modern Europe. In: Yolton JW, Brown LE, eds. Studies in Eighteenth-Century Culture. Vol. 18. East Lansing, Michigan, Colleagues Press, 1988, 7-37.

Mitchell SD. The Superorganism Metaphor: Then and Now. In: Maasen EMS, Weingart P, eds. Biology as Society, Society as Biology: Metaphors. Amsterdam, Kluwer, 1995, 231-248.

Moffett [Mouffet] T. The Theater of Insects: Or, Lesser Living Creatures. In: Topsell E, ed. The History of Four-Footed Beasts and Serpents. London, E. Cotes, 1658, 889-1130.

Nyhart LK. The Political Organism. Carl Vogt on Animals and States in the 1840 s and '50s. Historical Studies in the Natural Sciences 2017, 47 (5), 602-628, DOI: 10.1525/hsns.2017.47.5.602.

O'Neill E. Margaret Cavendish, Stoic Antecedent Causes, and Early Modern Occasional Causes. Revue Philosophique de la France et de l'Étranger 2013, 138 (3), 311-326.

Packham C. Eighteenth-Century Vitalism: Bodies, Culture, Politics. Basingstoke, Palgrave Macmillan, 2012.

Parikka J. Insect Media: An Archaeology of Animals and Technology. Minneapolis, University of Minnesota Press, 2010.

Pépin F. Vitalisme, Chimie et Philosophie Autour de l'Encyclopédie et de Diderot. In: Nouvel P, ed. Repenser le Vitalisme. Paris, PUF, 2011, 131-143.

Petkov S. The Fitness Landscape Metaphor: Dead but Not Gone. Philosophia Scientiæ 2015, 19 (1), 159-174, DOI: 10.4000/philosophiascientiae.1050.

Preston C. Bee. London, Reaktion Press, 2005.

Prete FR. Can the Female Rule The Hive? The Controversy over Honey-Bee Gender Roles in British Beekeeping Texts of the Sixteenth-Eighteenth Centuries. Journal of the History of Biology 1991, 24 (1), 113-144.

Purchas S. A Theatre of Politicall Flying-Insects wherein Especially the Nature, the Worth, the Work, the Wonder, and the Manner of Right-Ordering of the Bee, is Discovered and Described. London, Thomas Parkhurst, 1657.

Quiviger F. Honey from Heaven, Aspects of the Topos of the Bees in Renaissance Artistic Literature. In: Pfisterer U, Seidel M, eds. Visuelle Topoi, Erfindung und Tradiertes Wissen in den Künsten der Italienischen Renaissance. Munich, Berlin, Deutscher Kunstverlag, 2003, 317-321.

Réaumur RAFD. Suite de l'histoire des mouches à deux ailes, \& l'histoire de plusieurs mouches à quatre ailes, à savoir, des mouches à scies, des cigales, \& des abeilles. In: mémoires pour servir à l'histoire des insectes. Vol. 5. Paris, Imprimerie Royale, 1740.

Rey R. L’Âme, le corps et le vivant. In: Grmek M, ed. Histoire de la Pensée Médicale en Occident. Vol. 2. De la Renaissance aux Lumières. Paris, Seuil, 1997, 117-156.

Rey R. Naissance et développement du vitalisme en France de la deuxième moitié du 18e siècle à la fin du Premier Empire. Oxford, Voltaire Foundation, 2000, Abridged version of PhD thesis, 1987.

Roux S. Forms of Mathematization (14th-seventeenth Centuries). Early Science and Medicine 2010, 15, 319-337.

Roux S. Pour une étude des formes de la mathèmatisation. In: Chabotand $\mathrm{H}$, Roux $\mathrm{S}$, eds. La Mathématisation comme Problème. Paris, Éditions des archives contemporaines, 2011, 3-38.

Rusden M. A Full Discovery of Bees. Treating of the Nature, Government, Generation \& Preservation of the Bee. London, H. Million, 1685.

Schlanger J. Les métaphores de l'organisme. Paris, Vrin, 1971. 
Schmidgen W. Exquisite Mixture. The Virtues of Impurity in Early Modern England. Philadelphia, University of Pennsylvania Press, 2013.

Seeley TD. The Honey Bee Colony as a Superorganism. American Scientist 1989, 77, 546-553.

Seeley TD, Levien RA. A Colony of Mind: The Beehive as Thinking Machine. The Sciences 1987, 27, 38-43.

Sheehan J, Wahrman D. Invisible Hands: Self-Organization and the Eighteenth Century. Chicago, University of Chicago Press, 2015.

Smith JEH. Divine Machines: Leibniz and the Sciences of Life. Princeton, Princeton University Press, 2011.

Swift J. The Works of the Rev. Jonathan Swift. Vol. 2. London, John Nichols, 1801.

Theiner G, O'Connor T. The Emergence of Group Cognition. In: Corradini A, O'Connor T, eds.

Emergence in Science and Philosophy. New York, Routledge, 2010, 78-117.

Thompson DW. On Growth and Form. Abridged edition. Cambridge, Cambridge University Press, 1992. Thorley J. Melisselogia: Or, the Female Monarchy. London, 1744.

Tunstall K. The Early Modern Embodied Mind and the Entomological Imaginary. In: McMurran MH, Conway A, eds. Mind, Body, Motion, Matter: Eighteenth-Century British and French Literary Perspectives. Toronto, University of Toronto Press, 2016, 202-229.

Turner JS. Homeostasis is the Key to the Intelligent Building. Intelligent Buildings International 2016, 8 (2), DOI: 10.1080/17508975.2015.1042958.

Wallmann E. The Political Economy of Eighteenth-Century Insects: Natural History and Political Economy in France 1700-1789. PhD thesis, Warwick University, School of Modern Languages, 2017.

Warder J. The True Amazons: Or the Monarchy of Bees. London, John Pemberton, 1712.

Wenger A. Le Médecin et le Philosophe, Théophile de Bordeu selon Diderot. Paris, Hermann, 2012.

Wheeler WM. The Ant Colony as an Organism. Journal of Morphology 1911, 22 (2), 307-325, DOI: $10.1002 /$ jmor.1050220206.

Williams EA. A Cultural History of Medical Vitalism in Enlightenment Montpellier. Burlington, Ashgate, 2003.

Willis T. Pharmaceutice Rationalis, or an Exercitation of the Operations of Medicines in Human Bodies, 'Of Opiate Medicines on Causing Sleep. London, T. Dring, 1679.

Willis T. Two Discourses Concerning the Soul of Brutes, which is that of the Vital and Sensitive of Man. Trans. Pordage S. London, T. Dring, 1683.

Wolfe CT. Materialism. In: Garrett AV, ed. The Routledge Companion to Eighteenth-Century Philosophy. London, Routledge, 2014, 90-117.

Wolfe CT. Materialism. A Historico-Philosophical Introduction. Dordrecht, Springer, 2016.

Wolfe CT. Varieties of Vital Materialism. In: Ellenzweig S, Zammito J, eds. The New Politics of Materialism: History, Philosophy, Science. London, Routledge, 2017a, 44-65.

Wolfe CT. Vital Anti-Mathematicism and the Ontology of the Emerging life Sciences: From Mandeville to Diderot. Synthese 2017b, 196, 3633-3654, DOI: 10.1007/s11229-017-1350-y.

Wolfe CT. La philosophie de la biologie avant la biologie: une histoire du vitalisme. Paris, Garnier, 2019.

Wolfe CT, Terada M. The Animal Economy as Object and Program in Montpellier Vitalism. Science in Context 2008, 21 (4), 537-579, DOI: 10.1017/S0269889708001956.

Woolfson J. The Renaissance of Bees. Renaissance Studies 2010, 24 (2), 281-300.

Worlidge J. Apiarium, or a Discourse of Bees. London, T. Dring, 1676.

Sylvie Kleiman-Lafon is a senior lecturer in English literature at the Universite Paris 8-Vincennes à Saint-Denis. She is primarily interested in the use of literary forms in early-modern scientific discourse, and by the history of translation in the eighteenth century. She has edited Bernard Mandeville's Treatise of the Hypochondriack and Hysterick Diseases (Springer, 2017), and 
translated it into French (Ellug, 2012). She has co-edited (with Rebecca Anne Barr and Sophie Vasset) a volume on digestion as metaphor-Bellies, Bowels and Entrails in the eighteenth century (MUP, 2018), and another (with Micheline Louis-Courvoisier) on animal spirits -Les Esprits animaux 16e-21e siècles: littérature, histoire, philosophie (Épistémocritique, 2018). She is currently writing a monograph on Antoine Lasalle, translator of Francis Bacon's works into French at the end of the eighteenth century. Most papers available at https://univ-paris8.academia.edu/ SylvieKleimanLafon.

Charles T. Wolfe is a Professor in the Department of Philosophy, Université de Toulouse-2 JeanJaurés. He works primarily in history and philosophy of the early modern life sciences, with a particular interest in materialism and vitalism. He is the author of: Materialism: A HistoricoPhilosophical Introduction (2016), La philosophie de la biologie: une histoire du vitalisme (2019) and Lire le matérialisme (2020), and has edited or coedited volumes on monsters, brains, empiricism, biology, mechanism and vitalism, including currently (w. D. Jalobeanu) the Encyclopedia of Early Modern Philosophy and the Sciences and (w. J. Symons) The History and Philosophy of Materialism. He is co-editor of the book series 'History, Philosophy and Theory of the Life Sciences' (Springer). Papers available at https://univ-tlse2.academia.edu/CharlesWolfe. 
